Review

\title{
The riverine bioreactor: An integrative perspective on biological decomposition of organic matter across riverine habitats
}

\author{
Ignacio Peralta-Maraver ${ }^{\mathrm{a}, \mathrm{b}, *}$, Rachel Stubbington ${ }^{\mathrm{c}}$, Shai Arnon ${ }^{\mathrm{d}}$, Pavel Kratina ${ }^{\mathrm{e}}$, Stefan Krause ${ }^{\mathrm{f}}$, \\ Vivian de Mello Cionek ${ }^{\mathrm{g}}$, Nei Kavaguichi Leite ${ }^{\mathrm{h}}$, Aurea Luiza Lemes da Silva ${ }^{\mathrm{h}}$, Sidinei Magela Thomaz ${ }^{\mathrm{i}}$, \\ Ricardo Hideo Taniwaki ${ }^{r}$, James White ${ }^{\mathrm{s}}$, Gustavo Henrique Zaia Alves ${ }^{\mathrm{t}}$, Anne L. Robertson ${ }^{\mathrm{b}}$ \\ a Departamento de Ecología, Universidad de Granada, Granada, Spain \\ ${ }^{\mathrm{b}}$ Department of Life Sciences, Roehampton University, London, UK \\ c School of Science and Technology, Nottingham Trent University, Nottingham, UK \\ d Zuckerberg Institute for Water Research, The Jacob Blaustein Institutes for Desert Research, Ben-Gurion University of the Negev, Beersheba, Israel \\ e School of Biological and Chemical Sciences, Queen Mary University of London, London, UK \\ ${ }^{\mathrm{f}}$ School of Geography, Earth and Environmental Sciences, University of Birmingham, Edgbaston, Birmingham, UK \\ g Programa de Pós-Graduação em Ciência e Tecnologia Ambiental, Universidade do Vale do Itajaí, Itajaí, Santa Catarina, Brazil \\ ${ }^{\mathrm{h}}$ Department of Ecology and Zoology, Federal University of Santa Catarina, Florianópolis, Santa Catarina, Brazil \\ i Universidade Estadual de Maringá, Department of Biology, Maringá, Paraná, Brazil \\ ${ }^{\mathrm{j}}$ Department of Environmental Science, Stockholm University, Stockholm, Sweden \\ k School of Applied Sciences, University of Huddersfield, Huddersfield, UK \\ ${ }^{1}$ Cranfield Water Science Institute, Cranfield University, Cranfield, UK \\ ${ }^{\mathrm{m}}$ Laboratory of Aquatic Insect Ecology, Universidade Vila Velha, Vila Velha, Espírito Santo, Brazil \\ n Department of Life Sciences, Imperial College London, Silwood Park Campus, Buckhurst Road, Ascot SL5 7PY, UK \\ o Departamento de Ciências Ambientais, Universidade Federal de São Carlos, São Carlos, São Paulo, Brazil \\ p Department of Hydrobiology, Universidade Federal de São Carlos, São Carlos, São Paulo, Brazil \\ ${ }^{\mathrm{q}}$ Institute of Environmental Sciences, Leiden University, Leiden, the Netherlands \\ ${ }^{\mathrm{r}}$ Centro de Engenharia, Modelagem e Ciências Sociais Aplicadas, Universidade Federal do ABC, Santo André, São Paulo, Brazil \\ ${ }^{s}$ River Restoration Centre, Cranfield University, Cranfield, Bedfordshire, UK \\ t Departamento de Botânica, Universidade Federal do Paraná, Curitiba, Paraná, Brazil
} Malte Posselt ${ }^{\mathrm{j}}$, Victoria Susan Milner ${ }^{\mathrm{k}}$, Andrea Momblanch ${ }^{1}$, Marcelo S. Moretti ${ }^{\mathrm{m}}$, Rodolfo L.B. Nóbrega ${ }^{\mathrm{n}}$, Daniel M. Perkins ${ }^{b}$, Mauricio M. Petrucio ${ }^{\mathrm{h}}$, Isabel Reche ${ }^{\mathrm{a}}$, Victor Saito ${ }^{\mathrm{o}}$, Hugo Sarmento ${ }^{\mathrm{p}}$, Emily Strange ${ }^{\mathrm{q}}$,

\section{H I G H L I G H T S}

- We review the biologically driven decomposition processes that take place in riverine ecosystems.

- We identify important gaps in our understanding of decomposition processes in rivers from temperate and tropical biomes.

- We propose a novel analytical approach to predict decomposition processes from metabolic scaling theory.

- Using metadata from 30 rivers, we demonstrate that the slope of community size spectra can predict rates of decomposition.

\section{GRAPHICA L A B S T R A C T}
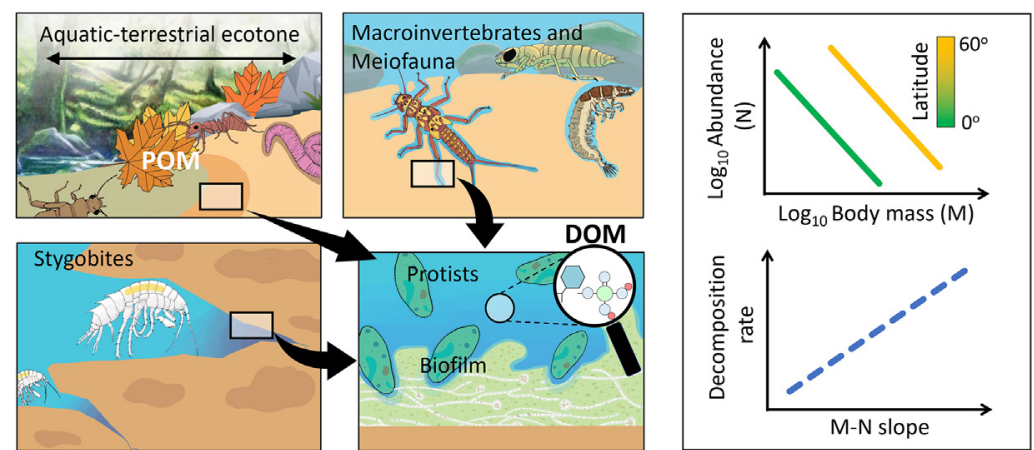

\footnotetext{
* Corresponding author at: Departamento de Ecología, Universidad de Granada, Granada, Spain.

E-mail address: peraltamaraver@ugr.es (I. Peralta-Maraver).
} 


\section{A R T I C L E I N F O}

\section{Article history:}

Received 6 October 2020

Received in revised form 21 January 2021

Accepted 25 January 2021

Available online 1 February 2021

Editor: Sergi Sabater

\section{Keywords:}

Body mass-abundance scaling

Biodegradation

Latitude

Metabolic theory

Riverine ecosystems

Regulating ecosystem service

\begin{abstract}
A B S T R A C T
Riverine ecosystems can be conceptualized as 'bioreactors' (the riverine bioreactor) which retain and decompose a wide range of organic substrates. The metabolic performance of the riverine bioreactor is linked to their community structure, the efficiency of energy transfer along food chains, and complex interactions among biotic and abiotic environmental factors. However, our understanding of the mechanistic functioning and capacity of the riverine bioreactor remains limited.

We review the state of knowledge and outline major gaps in the understanding of biotic drivers of organic matter decomposition processes that occur in riverine ecosystems, across habitats, temporal dimensions, and latitudes influenced by climate change.

We propose a novel, integrative analytical perspective to assess and predict decomposition processes in riverine ecosystems. We then use this model to analyse data to demonstrate that the size-spectra of a community can be used to predict decomposition rates by analysing an illustrative dataset. This modelling methodology allows comparison of the riverine bioreactor's performance across habitats and at a global scale.

Our integrative analytical approach can be applied to advance understanding of the functioning and efficiency of the riverine bioreactor as hotspots of metabolic activity. Application of insights gained from such analyses could inform the development of strategies that promote the functioning of the riverine bioreactor across global ecosystems.
\end{abstract}

(c) 2021 Elsevier B.V. All rights reserved.

\section{Contents}

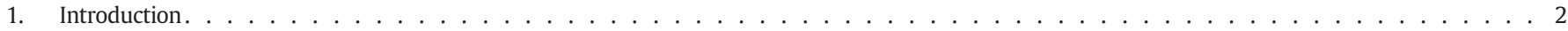

2. Decomposition of particulate organic matter in running waters. . . . . . . . . . . . . . . . . . . . . . . . . . . . 3

3. Decomposition of dissolved organic matter by the riverine bioreactor . . . . . . . . . . . . . . . . . . . . . . . . 4

4. Organic matter breakdown in aquatic-terrestrial ecotones . . . . . . . . . . . . . . . . . . . . . . . . . . . . 5

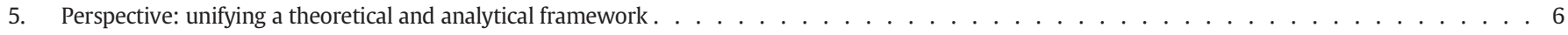

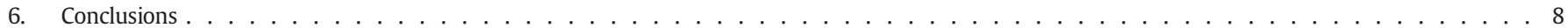

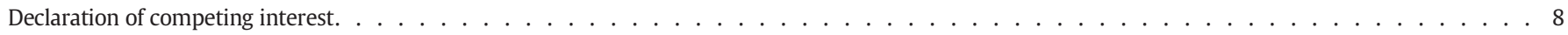

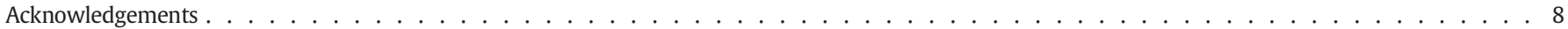

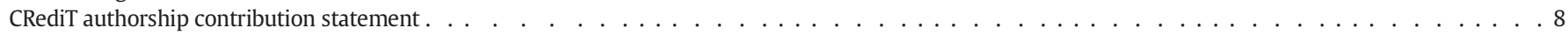

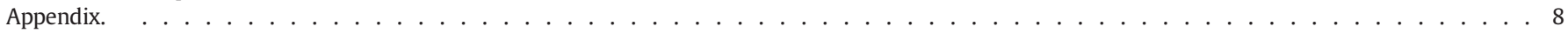

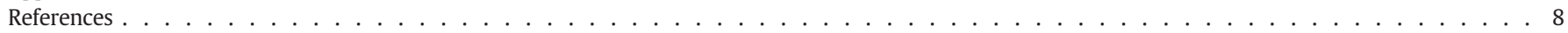

\section{Introduction}

Riverine ecosystems have the capacity to store, transform, and transfer inorganic nutrients, organic matter (OM), sediments and metabolites to adjacent ecosystems, such as marine environments and riparian forests (Battin et al., 2008; Benstead and Leigh, 2012). They can thus be conceptualized as bioreactors sustained and maintained by active communities (Krause et al., 2009; Peralta-Maraver et al., 2018). The habitats of riverine ecosystems include their surface water, streambeds, floodplains and alluvial aquifers, which are closely interconnected by energy and matter fluxes across bioactive interfaces (Krause et al., 2011a, 2011b, 2017). Rivers distribute decomposition over time and space, i.e. longitudinally, laterally and vertically, promoting the processing of a wide range of organic substrates, from highly recalcitrant particulate OM, such as some leaf litters and dissolved OM, to dissolved nutrients including pollutants of anthropogenic origin. It is estimated that riverine ecosystems produce an outgassing flux of $0.75-3.88 \mathrm{GtC} \mathrm{yr}^{-1}$ as a result of biological decomposition and chemical weathering (Raymond et al., 2013; Drake

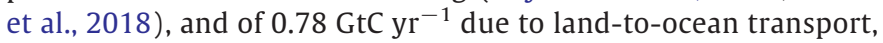
in which rivers play a major role (Friedlingstein et al., 2019). Riverine ecosystems also provide a range of services essential for human wellbeing, for example by contributing substantially to natural mitigation of inorganic and organic pollutants (Hill et al., 2014; PeraltaMaraver et al., 2018) and to the global carbon cycle (Battin et al., 2008; Hotchkiss et al., 2015).

Research into the decomposition of OM by riverine communities has experienced a rise in scientific activity in recent years, spanning disciplines including ecohydrology, community ecology, environmental pollution and global change science (e.g. Datry et al., 2018a, 2018b; Schaper et al., 2018, 2019; Tiegs et al., 2019). However, mechanistic understanding of biologically driven OM decomposition is limited for riverine ecosystems (hereafter, the riverine bioreactor) at low latitudes, where solar radiation, air and water temperatures, and rainfall intensity are markedly greater than at high latitudes (reviewed in Boulton et al., 2008). These major climatic drivers affect the rate at which OM enters aquatic ecosystems and is processed (Brandt et al., 2007; Wantzen et al., 2008; Tank et al., 2010).

Key gaps in our understanding of how biotic and abiotic drivers of the riverine bioreactor vary across latitudinal gradients and the transferability of concepts among regions. A unified analytical framework quantifying how OM decomposition responds to environmental constraints and ecological community structure is needed to assess these gaps. In addition, riverine ecosystems are increasingly exposed to multiple stressors driven by anthropogenic activities in a context of ongoing climate change, and such a framework might also indicate how the riverine bioreactor will respond to different stressor combinations.

We review how OM decomposition by the riverine bioreactor varies in response to latitude in longitudinal (headwater streams to lowland rivers), vertical (surface waters to aquifers), lateral (channel to floodplains and wetlands) and temporal dimensions. In doing so, we outline major anthropogenic stressors affecting bioreactor functioning. We also compare the state of understanding of riverine bioreactor functioning in temperate and low-latitude (tropical and subtropical) regions. We then propose an integrative analytical perspective to assess biologically driven OM decomposition processes, based on established concepts from the metabolic theory of ecology (Brown et al., 2004). Our work follows a hierarchical stepwise progression and establish solid knowledge 
foundations at every step before addressing the complex functioning of the riverine bioreactor (Fig. 1). Our ultimate goal is to provide a foundation on which to base further crosscutting research into the riverine bioreactor, by promoting interdisciplinary collaborations.

\section{Decomposition of particulate organic matter in running waters}

Rivers are generally heterotrophic ecosystems from source to mouth and across latitude (Vannote et al., 1980; Howarth et al., 1996; Wetzel, 2001; Follstad Shah et al., 2017), their functioning depending largely upon inputs of OM from autotrophic ecosystems, in particular leaf litter from the surrounding forested catchment. Thus, energy fluxes to riverine ecosystems are compromised by anthropogenic deforestation of riparian zones (Sponseller and Benfield, 2001), which reduces leaf litter and woody debris inputs. Riparian deforestation also limits shading, increasing solar radiation and water temperatures (Kelly et al., 2003; Johnson and Jones, 2000; Sweeney et al., 2004), which can reduce the diversity and metabolic activity of stream communities, resulting in lower decomposition rates (e.g. Silva-Araújo et al., 2020). This is of particular concern in tropical systems considering the greater rates of deforestation compared with temperate counterparts. For example, the Amazon basin has the world's highest rate of rainforest deforestation due to anthropogenic activities (Lepers et al., 2005; McClain and Elsenbeer, 2001).

The rate of leaf litter decomposition is naturally constrained by intrinsic litter characteristics, such as the concentrations of nutrients and secondary compounds, the decomposing capacities of aquatic communities across trophic levels, and climatic conditions (Webster and Benfield, 1986; McArthur et al., 1988; Thompson and Bärlocher, 1989; Gessner et al., 1999; Leite-Rossi et al., 2016; Follstad Shah et al., 2017; Peralta-Maraver et al., 2019a). Leaf litter decomposition pathways in rivers have been described in detail (e.g. Webster and Benfield, 1986; Gessner et al., 1999). In brief, after leaf litter falls into water, decomposition starts with the dissolution of labile compounds (leaching) and continues with microbial conditioning, consumption by invertebrates, fragmentation and physical abrasion (Webster and Benfield, 1986).
These processes gradually decompose leaf litter into gaseous respiration products such as carbon dioxide $\left(\mathrm{CO}_{2}\right)$, methane, nitrous oxide and molecular nitrogen (Gessner et al., 1999; Fig. 2a). POM decomposition typically depends on initial microbial conditioning by prokaryotes, fungi and protists, and later consumption by invertebrate shredders (e.g. Graça, 2001; Peralta-Maraver et al., 2019a). Leaf litter can accumulate on the streambed and is thus mostly decomposed by benthic communities (Peralta-Maraver et al., 2019a). However, leaf litter is buried and stored within the streambed sediments (i.e. the hyporheic zone; Cornut et al., 2010). Subsurface communities can be less active during leaf litter processing than benthic organisms (Peralta-Maraver et al., 2019a) and POM may thus accumulate in deeper sediments.

At the global scale, annual litterfall is notably higher in tropical rainforests than in both temperate deciduous broad-leaved and evergreen coniferous forests (Fig. 2a; Zhang et al., 2014). In contrast to the seasonal changes in temperature and leaf litter inputs that characterize temperate and boreal rivers, those in tropical and subtropical regions experience consistently warm temperatures and year-round OM inputs shed by highly productive riparian plants (Morellato et al., 2000). These riparian inputs are more abundant and diverse than those in temperate and boreal rivers (Bastian et al., 2007; Boyero et al., 2011a), in particular during periods of high rainfall. Higher temperatures at low latitudes also stimulate metabolic activity, microbial and invertebrate-mediated decomposition of OM compared to higher latitude systems (Taniwaki et al., 2017).

Species in stream communities at mid and high latitudes are adapted to marked seasonal inputs of litterfall from deciduous vegetation (Fig. 2a). The activity of detritivores adapted to autumnal litterfall pulses may explain the positive relationship between decomposition rates and absolute latitude, which accounts for the effect of temperature (Follstad Shah et al., 2017). Also, the abundance of relatively large-bodied detritivores and their contribution to leaf litter breakdown generally increase with latitude (Boyero et al., 2011a, 2011b). Thus, quantitative and/or qualitative differences in POM decomposition should occur along global latitudinal gradients, due to distinct climatic conditions and associated differences in riparian vegetation inputs (Boyero et al., 2009) and thus detritivore

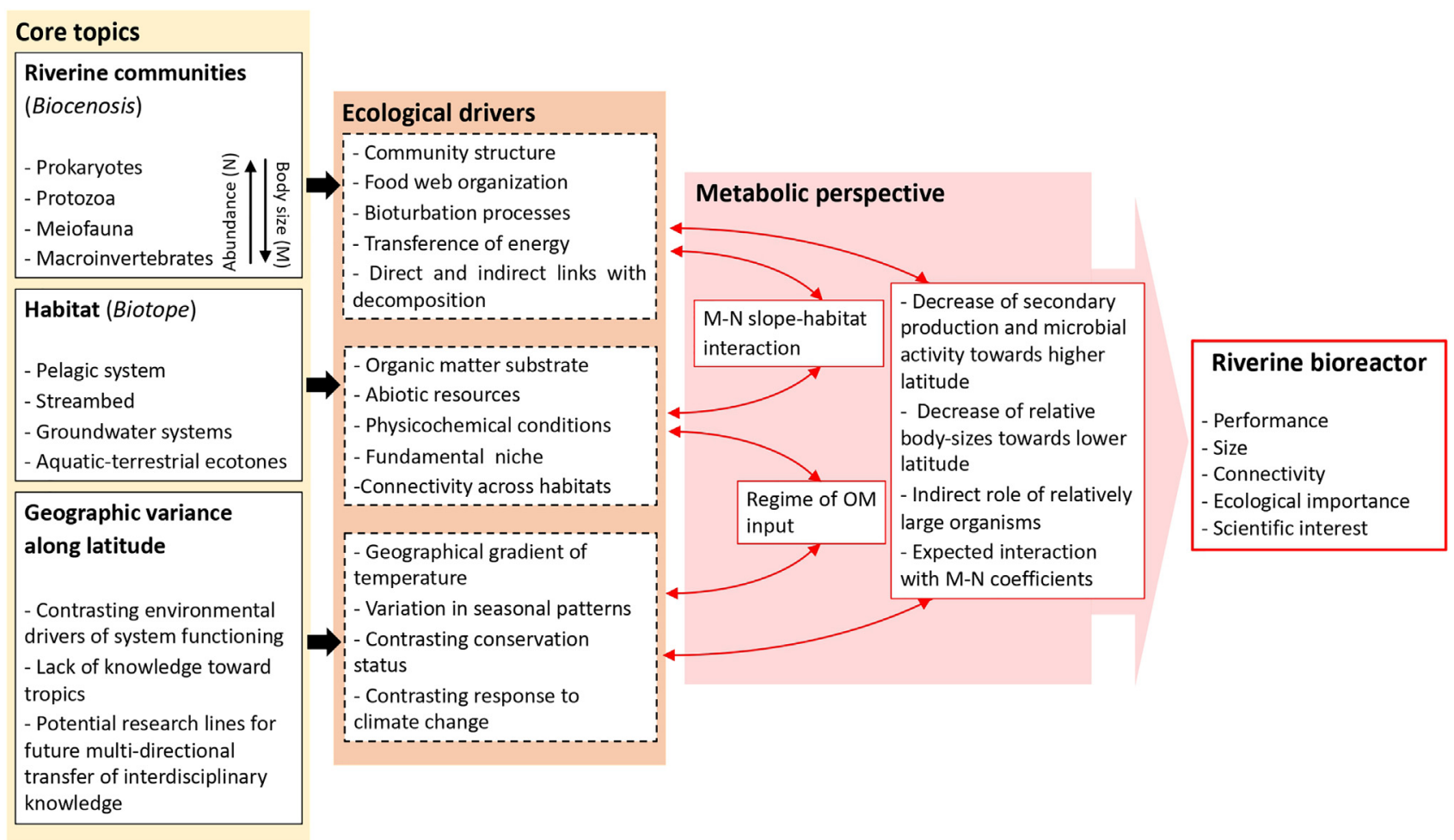

Fig. 1. Flow chart illustrating the hierarchy of knowledge that this review will follow through the different sections. 
a

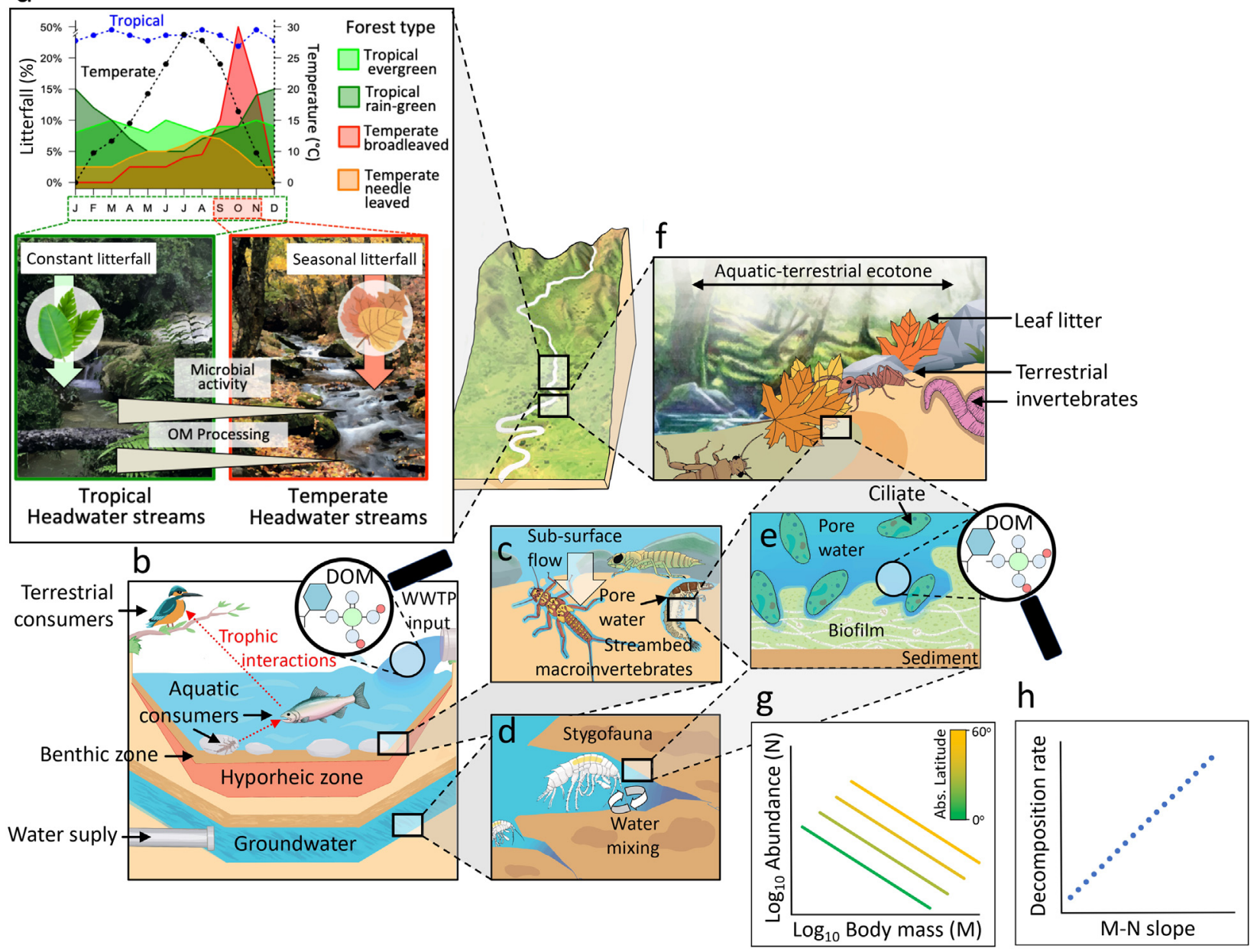

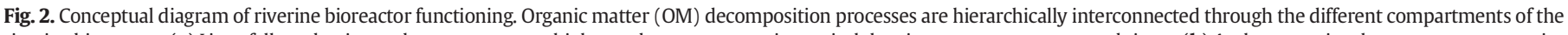

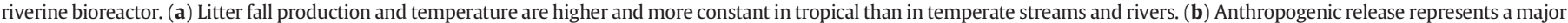

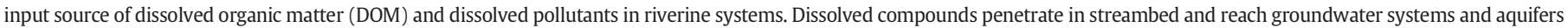

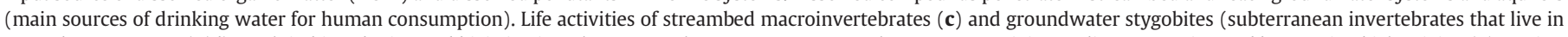

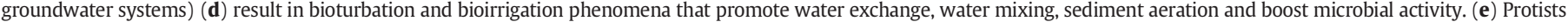

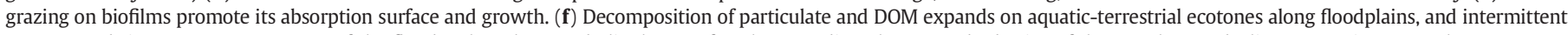

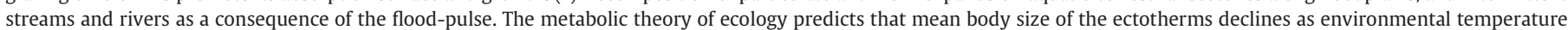

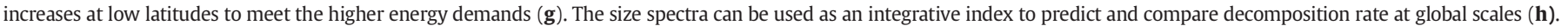

community composition, activity and dietary preferences (Boyero et al., 2009; Follstad Shah et al., 2017; Majdi and Traunspurger, 2017).

Species diversity of riparian litter inputs are negatively related to latitude (Benson and Pearson, 1993; Wright, 2002; Bastian et al., 2007), resulting in greater variability in the chemical characteristics and palatability of leaf litter in subtropical and tropical climates (Wantzen and Wagner, 2006). Because of the generalist feeding behavior of many invertebrate taxa, the importance of consumers that feed on leaf litter but are not classified as shredders might have been overlooked in tropical regions (Kelly et al., 2002; Leite-Rossi et al., 2016; Mendes et al., 2017). Additionally, the more diverse and abundant large-sized consumers inhabiting tropical streams, such as shrimps, crabs and 'herbivores' fish, might act as leaf litter consumers and directly influence decomposition rates (Boulton et al., 2008), and thus require consideration in litter breakdown modelling.

There is considerable intra-regional variability in the role of detritivores in leaf litter decomposition at low latitudes (Boyero et al., 2014). For example, streams in the vast, savanna-like Brazilian Cerrado ecoregion are characterized by unpalatable leaf litter and thus a scarcity of invertebrate shredders (Gonçalves et al., 2007). In addition, tropical soils typically export low concentrations of inorganic nutrients such as nitrogen and phosphorous to rivers, these nutrients being common factors limiting microbial activity in freshwaters (e.g. Pringle et al., 1986; Tank and Webster, 1998; Wold and Hershey, 1999). These nutrients probably limit decomposition rates in Cerrado streams by constraining the length of food chains. In contrast, the abundant shredders in some South American streams of the Atlantic Forest, Amazonian and Andean mountains process more OM, even in streams in which microorganisms make little contribution to leaf litter decomposition (Graça et al., 2016).

\section{Decomposition of dissolved organic matter by the riverine bioreactor}

Riverine ecosystems receive considerable dissolved OM from their catchments (Regnier et al., 2013) including significant anthropogenic inputs (Fig. 2b; Vitousek et al., 1997), and play an important role in transporting these allochthonous dissolved substances through landscapes. They also contribute to the retention and decomposition of dissolved OM, modifying the chemical forms and concentrations of dissolved compounds during transport (Rahm et al., 2016). For example, approximately two thirds of the dissolved carbon transported by rivers is estimated to be decomposed and mineralized before reaching the sea (Cole et al., 2007). Around 50\% 
of the total dissolved nitrate maybe processed during early stages of transport in headwater streams (Peterson et al., 2001), and 10-30\% of soluble reactive phosphorous can be retained in riverine sediments (reviewed in Withers and Jarvie, 2008). Abiotic factors such as geology and $\mathrm{pH}$ are important influences on the transformation and mineralization of dissolved OM (House, 2003; Refsgaard et al., 2014).

Planktonic microorganisms such as heterotrophic bacteria are key players in the decomposition of dissolved OM in freshwater (Seitzinger et al., 2006; Berggren and del Giorgio, 2015), due to their high extracellular enzymatic activity (Cunha et al., 2010). They support the flux of biomass and energy to higher trophic levels in surface water (Weitere et al., 2005) and bacterial respiration in the water column is a major contributor to dissolved organic carbon processing in inland waters (Raymond et al., 2013). Although bacterial respiration varies widely across globalscale, latitudinal gradients and rates are higher towards the equator (Aufdenkampe et al., 2011). Increasing dissolved inorganic nutrient concentrations enhance bacterial densities and biomass, which in turn promotes dissolved OM decomposition (Reche et al., 1998). Incorporation of dissolved organic carbon into microbial biomass is regulated by its concentrations and quality, and the abiotic conditions such as temperature (Findlay et al., 2001; Lennon and Cottingham, 2008; Williams et al., 2010). Lastly, chemical and thermal pollution can simplify microbial communities and increase or decrease their metabolic rates (Cherry et al., 1974; Schneider and Topalova, 2009; Wang et al., 2011). For example, microbial decomposition can increase along pollution gradients in response to inorganic nutrient availability (Pascoal et al., 2005) despite a decline in community diversity (Liao et al., 2018).

Significant quantities of dissolved compounds are also biologically processed by microbial biofilms attached to sediment particles (Battin et al., 2016). The high surface area provided by sediment particles within the streambed represents an active zone with a high capacity to decompose dissolved organic compounds (Fig. 2b; Krause et al., 2017; Peralta-Maraver et al., 2018). In particular for nitrogen organic compounds, streambed sediments can be hotspots of biological processing, such as biological assimilation (Alexander et al., 2000; Peterson et al., 2001). The intrinsic potential of the streambed to process nitrates, phosphates and organic carbon is well understood in temperate regions (e.g. Lewandowski et al., 2011), while it remains unexplored in tropical regions. In addition, the streambed can decompose emerging organic contaminants (EOCs, Lewandowski et al., 2011; Schaper et al., 2018; Posselt et al., 2020). However, channelization (the modification of a channel's banks and/or bed) suppresses the vertical connectivity between the surface and the streambed (Cleven and Meyer, 2003) and decreases the frequency of floodplain inundations (Nilsson et al., 2005), resulting in potential detriment of the riverine bioreactor functioning.

Current knowledge on the natural functioning of the riverine bioreactor comes from temperate-zone studies that focus on organic compound transformation in the surficial streambed sediments (e.g. Lewandowski et al., 2011; Schaper et al., 2018) and combine techniques at the interface of hydrology, biochemistry, microbiology and community ecology (e.g. Jaeger et al., 2019; Mechelke et al., 2019; Schaper et al., 2019; Posselt et al., 2020). Degradation of dissolved OM may also occur in deeper groundwater systems (Jurado et al., 2012), creating a vertical chain of biochemical breakdown processes through river sediments to groundwater ecosystems.

The metabolic activity of organisms inhabiting rivers in temperate regions contributes to active degradation of dissolved $\mathrm{OM}$, elimination of pathogens, and nutrient cycling in surface water, streambed and groundwater systems (Deng et al., 2014; Griebler and Avramov, 2015; Meckenstock et al., 2015; Hose and Stumpp, 2019; Reiss et al., 2019). Prokaryotes form biofilms with high enzyme activity, which enables their decomposition of a wide range of natural substrates (Battin et al., 2016). But also, they possess the potential to decompose new chemicals by developing new metabolic pathways (Kolvenbach et al., 2014). Prokaryotes often congregate in multi-species biofilms, maximizing the range of dissolved compounds that can be decomposed and the rate at which this degradation occurs (e.g. Foght, 2008).

Streambed and groundwater invertebrates (both meiofauna and macroinvertebrates) indirectly contribute to OM decomposition within the streambed (Peralta-Maraver et al., 2018). In temperate regions, macroinvertebrates directly influence the hydraulic properties of sediments through bioturbation and bioirrigation (Fig. 2c, d; Baranov et al., 2016a, 2016b; Hose and Stumpp, 2019). In addition, the mucus and silk secretions of benthic flatworms and caddisfly juveniles, respectively, stabilize sediments, and contribute to OM decomposition by enhancing biofilm development and invertebrates colonization (Majdi et al., 2014; Albertson et al., 2019). Groundwater macroinvertebrates may promote the abundance of Protozoa inhabiting interstitial pore spaces (Weitowitz et al., 2019), where protozoans swimming and grazing on biofilms promote water mixing, potentially increasing biofilm area and stimulating bacterial activity (Fig. 2e; Peralta-Maraver et al., 2018). These complex biotic interactions may enhance decomposition by the bioreactor, but the mechanisms behind this stimulatory response remains unknown.

Further studies need to explore global patterns in the biologically mediated decomposition of dissolved organic matter and the metabolic capacity of communities inhabiting streambed sediments. In temperate regions, the distribution of surface water and groundwater macroinvertebrate taxa (Sket, 1999; Danielopol et al., 2000; Gibert et al., 2009; Robertson et al., 2009) is reasonably well understood (Maurice and Bloomfield, 2012; Domisch et al., 2013), but our knowledge of microbial and protozoan population is rudimentary. The understanding of groundwater ecosystems functioning in tropical and subtropical regions lags even further behind that of temperate environments (Moosdorf et al., 2015; Adyasari et al., 2018). The mechanisms driving transformations of dissolved nutrients and contaminants in groundwater systems and the taxonomic groups related to decomposition processes require further study. For example, information on the distribution of surface water and groundwater macroinvertebrates in tropical regions is patchy, and much of our current limited knowledge of their role during decomposition processes derives from temperate regions. However, the relative contribution of different taxa may vary considerably across global latitudinal gradients due to differences in their metabolic rates and energy flow through trophic levels. Filling this knowledge gap is especially important given the occurrence of large-scale environmental accidents in tropical regions that pollute both surface and subsurface systems (e.g. Escobar, 2015; Cionek et al., 2019).

\section{Organic matter breakdown in aquatic-terrestrial ecotones}

Ecotones are transition or buffer zones between adjacent structurally different communities and habitat types, having a set of characteristics defined by space and time scales (Di Castri et al., 1988). Riverine ecosystems encompass habitats that shift between wet and dry states in space and time, acting as ecotones that support both aquatic and terrestrial communities. These dynamic aquatic-terrestrial ecosystems are distributed across river networks on all continents and in all climates, including temperate (Stubbington et al., 2017) and tropical (Barbosa et al., 2012) regions. Notably, an estimated half of the global river network comprises temporary streams, which experience partial or complete streambed drying (Tooth and Nanson, 2000; Datry et al., 2014). Furthermore, the number and length of temporary rivers is increasing globally due to increased water abstraction and higher intra-annual rainfall variability as a consequence of climate change (Jackson et al., 2001; Larned et al., 2010). Ecological functioning changes considerably between wet and dry states, but our understanding of organic matter processing during dry phases remain largely unexplored (Datry et al., 2017a).

Expansion and contraction of aquatic and terrestrial habitats also occur laterally in perennial systems, in particular floodplain environments, which are among the most productive and biochemically active 
systems in the world (Junk et al., 1989). In the middle and lower river sections, flooding of the main channel and tributaries typically creates a mosaic of aquatic and terrestrial habitats on floodplains. Even though river-floodplain systems may maintain water flow throughout the year, their aquatic-terrestrial transition zones remain dry for all or most of the low during the low water season (Junk et al., 1989). Floodplains support the functioning of riverine bioreactor, as they act as sediment traps, sinks for dissolved nutrients and chemicals, and as large carbon stores (Baigún et al., 2008; Walalite et al., 2016), and supply channels with a diversity of organic substrates and associated microbial decomposers (O'Connell et al., 2000).

Dynamic aquatic-terrestrial habitats including temporary rivers and floodplains have different characteristics to those of adjacent riparian, purely terrestrial and fully aquatic habitats, and support unique communities, including inundation-tolerant terrestrial colonists (Tockner and Stanford, 2002; Steward et al., 2011) and desiccation-tolerant aquatic organisms (Stubbington and Datry, 2013; Datry et al., 2017b) during dry phases. During transitions from aquatic to terrestrial phases, drivers of organic matter decomposition such as leaching and aquatic decomposers, are gradually replaced by physical photodegradation and terrestrial colonists, such as soil fauna and fungi (Fig. 2f; Austin and Vivanco, 2006; Corti et al., 2011; Arce et al., 2019). These transitional aquatic-terrestrial dynamics promote organic matter decomposition and mineralization process in inland waters (Datry et al., 2018a, 2018b). Organic matter decomposition might be also enhanced if biofilm activity increases in response to sediment reworking by terrestrial soil invertebrates (Fig. 2f; Prather et al., 2013).

The timing, frequency, duration and magnitude of wet and dry phases defines the structure and metabolic capacity of communities inhabiting aquatic-terrestrial channels and floodplains (Adis and Junk, 2002; Stubbington et al., 2017; Colls et al., 2019) and interrupts both decomposition rates and OM quality (Padial and Thomaz, 2006). Consequently, wet phases promote decomposition within floodplains, as in temporary streams and rivers (Datry et al., 2018a, 2018b; Von Schiller et al., 2019). This is because, rewetting events in temporary systems create 'hot moments' of biological activity, initiating pulses of organic matter decomposition that contribute significantly to carbon cycling (Datry et al., 2018a, 2018b; Shumilova et al., 2019; Von Schiller et al., 2019). Repeated inundation of aquatic-terrestrial channels and floodplains may be analogous to conditions in floodable soil aquifer treatment (SAT) systems in wastewater plants. SAT systems release time-controlled flood pulses of secondary effluents from conventional wastewater treatment through a recharge basin, with posterior wastewater processing dominated by biodegradation in the sediments (Amy and Drewes, 2007; Arye et al., 2011). During dry phases, terrestrial colonists such as, nematodes, annelids and arthropods (e.g. ants), can transform plant litter and fine POM into constituent nutrients by consumption and egestion, and thus support particulate nutrient cycling in the whole river ecosystem (Bush et al., 2019).

Rewetting events vary considerably across latitudinal gradients. In boreal and high latitude temperate regions, the timing of wet and dry phases can be predictable, in response to seasonal changes in precipitation and snowmelt (Olsson and Söderström, 1978; Gasith and Resh, 1999 ) inputs. However, the magnitude of flood pulses could vary considerably among wet and dry years at mid-latitudes, for example in many Mediterranean streams (Bonada and Resh, 2013). Flood pulses can be marked and predictable in some tropical rivers due to the extended wet season (Boulton et al., 2008). But, the higher annual precipitation in wet subtropical and tropical regions results in frequent and irregular flood pulses, which structure communities including biofilms (Taniwaki et al., 2019; Burrows et al., 2020) and benthic macroinvertebrates (Nessimian et al., 1998). Nonetheless, the higher frequency and magnitude of flood pulses has not been related to decomposition processes at low latitudes. Global predictions of bioreactor capacity in aquatic-terrestrial channels and floodplains should seek to integrate the effects of flood pulses on community structure and energy flow through food webs with quantified decomposition rates (Shumilova et al., 2019).

\section{Perspective: unifying a theoretical and analytical framework}

Throughout this paper, we acknowledge that a wide range of different sized organisms with different functional roles contribute directly or indirectly to decomposition processes. For example, consortia of prokaryotes and eukaryotic microorganisms form biofilms and drive initial leaf litter decomposition through extracellular digestion, making substrates more palatable to macroinvertebrate consumers. In addition, the enzymatic activity of sediment biofilms and planktonic prokaryotes enables them to process a breadth of dissolved organic substrates (from macronutrients to pollutants). In addition, the activity of grazers and burrowers boost microbial activity.

Collectively, complex interactions between biotic groups within riverine communities and their environments mediate the functioning of the riverine bioreactor. However, research documenting organic matter decomposition typically considers only certain community groups, which typically have different trophic roles (e.g. microbial conditioning vs. macroinvertebrate shredding leaf litter). In addition, compared to both microorganisms and macroinvertebrates, the contribution of meiofauna to organic matter decomposition in freshwater ecosystems remains poorly characterized (Majdi et al., 2020, but see Wang et al., 2020). These size biases limit incorporation of quantitative measurements of energy and biomass flow through communities when studying decomposition phenomena. In addition, research into decomposition processes has not characterized variation in community structure and energy transfer across latitudinal gradients. Integrative analyses that represent entire communities and global-scale variability are needed to better understand the biologically driven decomposition processes in riverine ecosystems.

Changing temperatures are one of the most conspicuous differences among river ecosystems along a latitudinal gradient. Environmental temperature is a key influence on metabolic rates, body size, growth rates, feeding rates and consequently decomposition rates in aquatic ecosystems (Brown et al., 2004). Thus, incorporating environmental temperature and the scaling between the metabolic rates and body size of aquatic ectotherms represents a step towards extrapolation of empirical findings from temperate ecosystems to processes in lesser-studied tropical ecosystems. In this sense, metabolic scaling (sensu Brown et al., 2004; Sibly et al., 2012) provides the theoretical and analytical framework that links the energetic constraints of individuals to ecosystem-level processes. Thus, this framework can be used to assess biotic controls on organic matter decomposition - even between stream habitats and across biomes.

Metabolic rates of ectotherms increase with organism body size and environmental temperature (Brown et al., 2004). For instance, metabolic rates of metazoans often scale with body mass as a power law with an exponent of $3 / 4$, which is predicted by optimal resource supply networks (Brown et al., 2004). Because an individual's performance reflects its mass-dependent metabolic requirements, an assemblage's capacity to process metabolic substrates therefore depends on both its total biomass, and how biomass is apportioned among small or large individuals. Consequently, total biomass and the size structure of ecological communities are important predictors of ecosystem processes governed by consumers, such as the decomposition of particulate organic matter, dissolved OM, including organic pollutants.

Body mass-abundance (M-N) scaling relationships provide a potential bridge between an assemblage's metabolic capacity and the bioreactor capacity of a system. When individual organisms are grouped into body-mass classes, irrespective of taxonomic identity, the negative slope of the resultant frequency distributions on double-log axes (i.e. size- spectra; White et al., 2007) provides a measure of community size structure, and the area under the slope (and intercept) provides a measure of total biomass (Fig. $2 \mathrm{~g}$ ). This relationship is defined by the equation Eq. (1): 
Abundance $(N) \sim \beta_{0}+$ body mass $(M)+\varepsilon$,

where $ß 0$ is the intercept and $\varepsilon$ an error term.

Freshwater communities are structured by body size, which is inversely proportional to population densities (Schmid et al., 2000). Also, the body size of different groups can provide an indication of trophic level in hyporheic food web (Kerr and Dickie, 2001), despite some exceptions should be considered (e.g. parasites; Leaper and Huxham, 2002). This allows the size-spectrum slope act as a proxy for a community's metabolic efficiency (i.e. its capacity to transfer energy and biomass through trophic levels). Metabolic scaling coefficients (slope and intercept of size-spectra) could be used to predict bioreactor capacity, based primarily on universal body-mass constraints on individual metabolism and information on food web (Brown et al., 2004; Petchey and Belgrano, 2010). The size-spectrum slope (M-N slope) scales with the efficiency of energy transfer across trophic levels (Brown and Gillooly, 2003), and typically becomes steeper as metabolic efficiency decreases (e.g. abundance decreases dramatically from low to high trophic levels; Kerr and Dickie, 2001; Perkins et al., 2018). Consequently, a strong positive relationship is predicted between a system's size-spectrum slope and its decomposition capacity, allowing slopes to predict and quantify decomposition rates (Fig. $2 \mathrm{~h}$ ).

Metabolic scaling theory, therefore, provides a potentially powerful approach to reconcile differences in organic matter decomposition among riverine habitats and across latitudinal gradients, within the analytical rationale that established measurements of decomposition rates (Woodward et al., 2012) can be used to determine the exponential decay coefficient ( $\boldsymbol{k})$ using Eq. (2):

Decomposition rate $(\boldsymbol{k})=-\left(\log \left(X_{t}\right)-\log \left(X_{0}\right)\right) / t$

where $X_{0}$ represents the initial quantity of an organic matter substrate, and $X_{t}$ represents the quantity of substrate remaining at time $t$. The exponential coefficient $t$ should be expressed in terms of thermal sums (degree days) to correct for potential temperature effects and/or differences in sampling duration. Based on our premises, Eq. (2) can be combined with Eq. (1) to build a predictive model of the decomposition rate as:

Decomposition rate $(\boldsymbol{k}) \sim \beta_{0}+$ habitat $\times M-N$ slope + latitude

$$
\times M-N \text { slope }+\varepsilon
$$

Where predictor $M-N$ slope have both an additive and interactive effect on the response decomposition rate due to its strong sensitivity to temperature (e.g. Dossena et al., 2012; O'Gorman et al., 2017) and its habitat-dependency in riverine systems (Peralta-Maraver et al., 2019b). Note that habitat and latitude do not drive abundance themselves, but integrate the variability in abiotic factors such as dissolved oxygen concentrations and temperature.

To test our analytical framework, we used data from PeraltaMaraver et al. (2019a) describing POM breakdown across 30 UK rivers (Fig. 3a). This study used measurements of organic matter decomposition rates $(k)$ using a standardized bioassay. PeraltaMaraver et al. (2019a) measured decomposition rates and provide fine-resolution data describing the body size and abundance of prokaryotes, protists, meiofauna and macroinvertebrates. In addition, the authors distinguished communities inhabiting benthic (0-5 cm depth) and hyporheic (15 cm depth) habitats. We applied Eq. (1) to build $60 \mathrm{M}-\mathrm{N}$ scaling curves (30 rivers by two habitats), showing a considerably steeper M-N relationship in hyporheic compared to benthic habitats (Fig. 3b). Other measured abiotic variables (e.g. pH) were excluded to facilitate model performance. The M-N slope is a powerful predictor of decomposition rates $\left(R^{2}=0.60\right.$, Fig. $\left.3 c\right)$. Details of the model selection approach, model fitting, and model coefficients are provided in the Appendix.

Our analysis did not include latitude or temperature due to insufficient variability at the regional scale, and thus the validation of our framework is still limited to temperate systems. In warmer subtropical and tropical regions, organism size tends to decline with increasing temperature due to greater energetic costs (James, 1970; Atkinson, 1994; Evans et al., 2020). Furthermore, greater energetic demands should reduce population carrying capacity with increasing temperature (Bernhardt et al., 2018, but see O'Gorman et al., 2017), assuming a fixed supply of resources (Brown et al., 2004). Thus, relative consumer abundance may be lower at low latitudes compared to temperate and boreal systems (Heino et al., 2018), but low-latitude consumers may be more productive, because higher temperatures limit body sizes and smaller species have higher biomass.

turnover rates. Such potential differences in productivity, as well as differences in the thermal conditions, mean that the capacity of assemblages to drive metabolic processes that underpin organic matter decomposition likely varies with latitude, with consequences for delivery of related ecosystem services. a

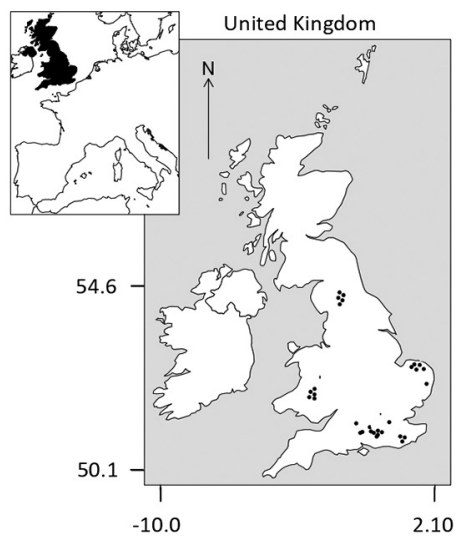

b

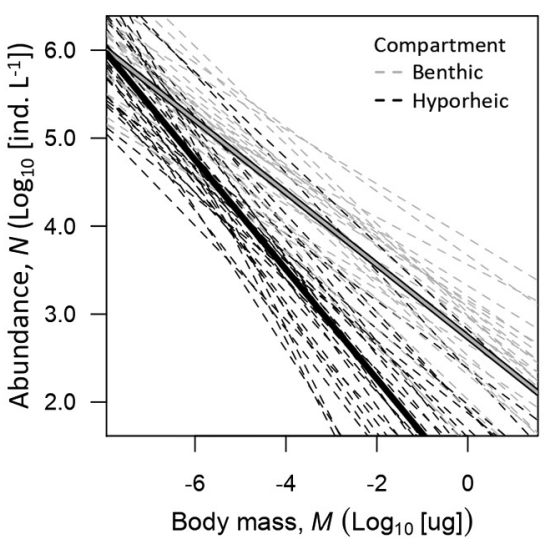

C

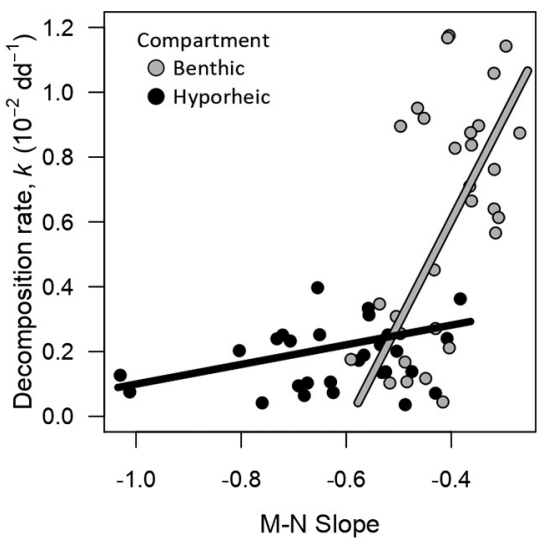

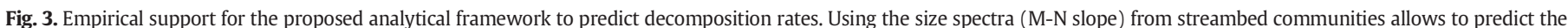

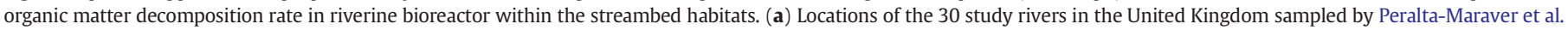

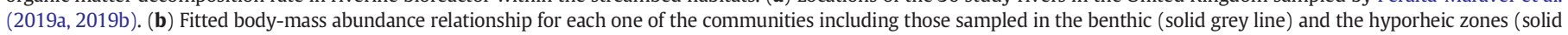
black line). (c) Predicted relationship between the M-N slope and the decomposition rate measured in degree days (dd) for each habitat. 
Metabolic scaling theory is based on a few key variables (body size and temperature) and deviations from expected scaling patterns can indicate the influence of additional factors (Perkins et al., 2018). For example, in many contexts, both biotic interactions and abiotic constraints likely modify the expression of body size as well as temperature scaling patterns. It could enable prediction of bioreactor capacity in riverine ecosystems across latitudes at which the nature and strength of biotic interactions differ (Schemske et al., 2009; González-Bergonzoni et al., 2012). The use of M-N scaling coefficients as predictors of decomposition rates also integrate the effects of environmental constraints, such as dry and wet phases in aquatic-terrestrial ecotones. Although multiple interacting mechanisms affect the bioreactor capacity of riverine ecosystems along global latitudinal gradients, metabolic scaling offers a valuable framework to understand and predict differences in the decomposition of OM at large spatial scales.

\section{Conclusions}

Organic matter decomposition pathways are highly interconnected and extend through and beyond multiple river habitats. Thus, to better understand and, predict riverine bioreactor functioning, integrative analytical approaches are required, such as those provided by the metabolic scaling theory (Brown et al., 2004). This understanding could be advanced by quantitative meta-analysis of data documenting processes such as leaf litter and dissolved OM decomposition, supplemented by data describing community size-spectra coefficients, as in our models. New data are needed to document and predict OM decomposition rates on: (1) interactions between climate and riparian inputs at global scales; (2) latitudinal variability in dry-wet transitions as a driver of decomposition processes in aquatic-terrestrial ecotones; (3) the contributions of terrestrial and aquatic organisms to decomposition in aquatic-terrestrial systems; (4) the indirect effects of different biotic groups on decomposition processes (e.g. through bioturbation, decomposer grazing); (5) the contribution of meiofauna and microfauna; (6) the contribution of groundwater invertebrates across latitudes; (6) vertical changes in decomposition processes between surface water and aquifers; (7) the M-N scaling coefficients that enable prediction of decomposition in different regions; and ( 8 ) the response of decomposition processes to specific anthropogenic stressors.

The higher temperatures and/or higher productivity of relatively small-bodied consumers at lower latitudes (Heino et al., 2018) warrant comparative global-scale studies of bioreactor capacity. Global efforts should quantify and evaluate the regulating ecosystem services provided by the riverine bioreactor. Then, suitable management strategies could be developed to maintain, or even enhance the delivery of ecosystem services by riverine ecosystems locally. Building partnerships between international teams will enable transfer of world-leading knowledge, expertise and cutting-edge methodologies on freshwater research and management. This is especially important considering the time pressures that ongoing global change impose on decisionmaking.

\section{Declaration of competing interest}

The authors declare that they have no known competing financial interests or personal relationships that could have appeared to influence the work reported in this paper. All authors agreed on its publication in the current form.

\section{Acknowledgements}

We would like to express our gratitude to Dr. Manuel Jesús López-Rodríguez and Dr. José Manuel Tierno de Figueroa for their valuable suggestions during the preparation of the manuscript. We also thank the two anonymous reviewers, whose useful comments improved significantly both the modelling part and the theoretical content of the manuscript. Lastly, we also thank Dr. Enrico L. Rezende, who provided useful guidance on the representation of the results from our modelling approach. This work was funded by a Researcher Links grant, ID: 10592, under the Newton-Brazil fund awarded to AR and MP. The grant is funded by the UK Department of Business, Energy and Industrial Strategy (BEIS) and Fundação de Amparo à Pesquisa e Inovação do Estado de Santa Catarina (FAPESC) and delivered by the British Council. PK acknowledges funding from the Royal Society, Newton Advanced Fellowship (grant no. NAF/R2/180791).

\section{CRediT authorship contribution statement}

IP-M and AR conceived this study and led the article. All authors contributed during preparation, editing and reviewing of the original draft including the main text, figures and tables, and preparation of the final version. All authors gave final approval for publication.

\section{Appendix}

We analysed data from a large regional scale survey (Peralta-Maraver et al., 2019a). Data were collected at 30 study sites covering 10 catchments across England and Wales. Systems varied from small upland, acidic headwater streams, to large lowland, base-rich chalk streams. Raw data include measurements of multiple environmental variables representing each sampling site such as $\mathrm{pH}$, water depth, canopy cover, and others (see PeraltaMaraver et al., 2019a). Streambed communities were sampled using colonization traps ( $\mathrm{mesh}=0.5 \mathrm{~cm}$, volume $=38-45 \mathrm{~mL}$ ) containing an organic bioassay (cotton-strips assay), as a standardized measure of leaf litter decomposition (Tiegs et al., 2019). Three traps per sampling site where deployed in the original study, and we averaged decomposition and community measurements by stream and habitat to maximize representation of the streambed community per sampling unit.

Decomposition rate was calculated applying Eq. (2) (Woodward et al., 2012). Sampled organisms were identified and counted (N) and their body dimensions (width and length) measured then transformed into dry body-mass (M) with established allometric relationships (Peralta-Maraver et al., 2019a).

We constructed the M-N scaling relationships for each site and habitat using the logarithmic size-binning method (Edwards et al., 2017) and applying Eq. (1). Size bins were determined from the (log10) body mass (M) range for each sampled community and the abundances of organisms were then summed within each size bin (White et al., 2007). Six bins were used to maximize the number of size bins while minimizing the number of empty size bins (Perkins et al., 2018).

Finally, a model selection approach based on the Akaike information criterion (AIC) was applied to determine whether habitat and M-N scaling coefficients predict the decomposition rate. Latitude was not included in the analysis due to the low variability across study sites. Model selection routines identified the model including an interaction between M-N slope and habitat (Eq. (3)) on decomposition rate ( $k$ ) as the best candidate (Table A1). Model assumptions of normality and homoscedasticity of the residuals and the presence of influential observations were validated visually following (Zuur et al., 2009). Results from the model evidenced a strong positive effect of the M-N slope on the decomposition rate of leaflitter (Table A2). 
Table A1

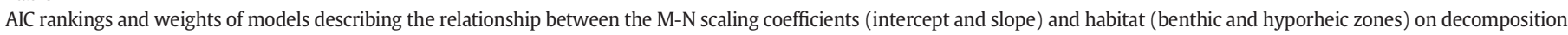

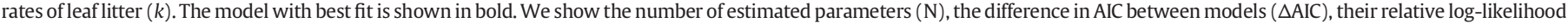
and weights (wi).

\begin{tabular}{|c|c|c|c|c|c|}
\hline Model & $\mathrm{N}$ & AIC & $\triangle \mathrm{AIC}$ & Log-lik & $w i$ \\
\hline$k \sim$ habitat & 3 & -517.60 & 16.50 & $0.03 \times 10^{-2}$ & $0.02 \times 10^{-2}$ \\
\hline$k \sim$ habitat $+M-N$ intercept & 4 & -520.70 & 13.40 & $0.12 \times 10^{-2}$ & $0.07 \times 10^{-2}$ \\
\hline$k \sim$ habitat $+M-N$ slope & 4 & -521.60 & 12.50 & $0.19 \times 10^{-2}$ & $0.12 \times 10^{-2}$ \\
\hline$k \sim$ habitat $+M-N$ intercept $+M-N$ slope & 5 & -519.70 & 14.40 & $0.07 \times 10^{-2}$ & $0.05 \times 10^{-2}$ \\
\hline$k \sim$ habitat $+M-N$ intercept + habitat $\times M-N$ intercept & 5 & -525.80 & 8.30 & $1.54 \times 10^{-2}$ & $0.93 \times 10^{-2}$ \\
\hline$k \sim$ habitat $+M-N$ slope + habitat $\times M-N$ slope & 5 & -534.10 & 0.00 & 1.00 & 0.60 \\
\hline$k \sim$ habitat $+M-N$ intercept $+M-N$ slope + habitat $\times M-N$ intercept & 6 & -526.80 & 7.30 & $2.53 \times 10^{-2}$ & 0.01 \\
\hline$k \sim$ habitat $+M-N$ intercept $+M-N$ slope + habitat $\times M-N$ slope & 6 & -532.50 & 1.60 & 0.45 & 0.27 \\
\hline$k \sim$ habitat $+M-N$ intercept $+M-N$ slope + habitat $\times M-N$ intercept + habitat $\times M-N$ slope & 7 & -530.54 & 3.57 & 0.16 & 0.10 \\
\hline
\end{tabular}

Table A2

Summary statistics of the best fitting model $\left(R^{2}=0.60\right.$, see Table A.1).

\begin{tabular}{|c|c|c|c|c|}
\hline & Coefficient & SE & t-value & $p$-value \\
\hline Intercept & 0.02 & $0.22 \times 10^{-2}$ & 7.42 & \\
\hline Habitat & -0.01 & $0.29 \times 10^{-2}$ & -4.73 & $<0.01 \times 10^{-2}$ \\
\hline$M-N$ slope & 0.02 & $0.52 \times 10^{-2}$ & 4.75 & $<0.01 \times 10^{-2}$ \\
\hline Habitat $\times$ M-N slope & -0.02 & $0.60 \times 10^{-2}$ & -3.91 & $<0.01 \times 10^{-2}$ \\
\hline
\end{tabular}

\section{References}

Adis, J., Junk, W.J., 2002. Terrestrial invertebrates inhabiting lowland river floodplains of Central Amazonia and Central Europe: a review. Freshw. Biol. 47 (4), 711-731. https://doi.org/10.1046/j.1365-2427.2002.00892.x.

Adyasari, D., Oehler, T., Afiati, N., Moosdorf, N., 2018. Groundwater nutrient inputs into an urbanized tropical estuary system in Indonesia. Sci. Total Environ. 627, 1066-1079. https://doi.org/10.1016/j.scitotenv.2018.01.281.

Albertson, L.K., Sklar, L.S., Cooper, S.D., Cardinale, B.J., 2019. Aquatic macroinvertebrates stabilize gravel bed sediment: a test using silk net-spinning caddisflies in seminatural river channels. PLoS One 14 (1), e0209087. https://doi.org/10.1371/journal. pone.0209087.

Alexander, R.B., Smith, R.A., Schwarz, G.E., 2000. Effect of stream channel size on the delivery of nitrogen to the Gulf of Mexico. Nature 403 (6771), 758-761. https://doi.org/ $10.1038 / 35001562$

Amy, G., Drewes, J., 2007. Soil aquifer treatment (SAT) as a natural and sustainable wastewater reclamation/reuse technology: fate of wastewater effluent organic matter (EfOM) and trace organic compounds. Environ. Monit. Assess. 129 (1-3), 19-26. https://doi.org/10.1007/s10661-006-9421-4

Arce, M.I., Mendoza-Lera, C., Almagro, M., Catalán, N., Romaní, A.M., Martí, E., ... Marcé, R., 2019. A conceptual framework for understanding the biogeochemistry of dry riverbeds through the lens of soil science. Earth-Sci. Rev. 188, 441-453. https://doi.org/ 10.1016/j.earscirev.2018.12.001.

Arye, G., Dror, I., Berkowitz, B., 2011. Fate and transport of carbamazepine in soil aquifer treatment (SAT) infiltration basin soils. Chemosphere 82 (2), 244-252. https://doi. org/10.1016/j.chemosphere.2010.09.062.

Atkinson, D., 1994. Temperature and organism size: a biological law for ectotherms? Adv. Ecol. Res. 25 (3), 1-58. https://doi.org/10.1016/S0065-2504(08)60212-3.

Aufdenkampe, A.K., Mayorga, E., Raymond, P.A., Melack, J.M., Doney, S.C., Alin, S.R., ... Yoo, K., 2011. Riverine coupling of biogeochemical cycles between land, oceans, and atmosphere. Front. Ecol. Environ. 9 (1), 53-60. https://doi.org/10.1890/100014.

Austin, A.T., Vivanco, L., 2006. Plant litter decomposition in a semi-arid ecosystem controlled by photodegradation. Nature 442 (7102), 555-558. https://doi.org/10.1038/ nature 05038

Baigún, C.R.M., Puig, A., Minotti, P.G., Kandus, P., Quintana, R., Vicari, R., ... Nestler, J.A., 2008. Resource use in the Parana River Delta (Argentina): moving away from an ecohydrological approach? Ecohydrol. Hydrobiol. 8 (2-4), 245-262. https://doi.org/ 10.2478/v10104-009-0019-7.

Baranov, V., Lewandowski, J., Krause, S., 2016a. Bioturbation enhances the aerobic respiration of lake sediments in warming lakes. Biol. Lett. 12 (8), 20160448. https://doi.org/ $10.1098 / \mathrm{rsbl} .2016 .0448$

Baranov, V., Lewandowski, J., Romeijn, P., Singer, G., Krause, S., 2016b. Effects of bioirrigation of non-biting midges (Diptera: Chironomidae) on lake sediment respiration. Sci. Rep. 6, 27329. https://doi.org/10.1038/srep27329.

Barbosa, J.E.D.L., Medeiros, E.S.F., Brasil, J., Cordeiro, R.D.S., Crispim, M.C.B., Silva, G.H.G.D., 2012. Aquatic systems in semi-arid Brazil: limnology and management. Acta Limnol. Bras. 24 (1), 103-118. https://doi.org/10.1590/S2179-975X2012005000030.

Bastian, M., Boyero, L., Jackes, B.R., Pearson, R.G., 2007. Leaf litter diversity and shredder preferences in an Australian tropical rain-forest stream. J. Trop. Ecol. 23 (2) 219-229. https://doi.org/10.1017/S0266467406003920.

Battin, T.J., Kaplan, L.A., Findlay, S., Hopkinson, C.S., Marti, E., Packman, A.I., Newbold, A.I., Sabater, F., 2008. Biophysical controls on organic carbon fluxes in fluvial networks. Nat. Geosci. 1, 95. https://doi.org/10.1038/ngeo101.
Battin, T.J., Besemer, K., Bengtsson, M.M., Romani, A.M., Packmann, A.I., 2016. The ecology and biogeochemistry of stream biofilms. Nat. Rev. Microbiol. 14 (4), 251. https://doi. org/10.1038/nrmicro.2016.15.

Benson, L.J., Pearson, R.G., 1993. Litter inputs to a tropical Australian rainforest stream. Aust. J. Ecol. 18 (4), 377-383. https://doi.org/10.1111/j.1442-9993.1993.tb00465.X.

Benstead, J.P., Leigh, D.S., 2012. An expanded role for river networks. Nat. Geosci. 5 (10) 678-679. https://doi.org/10.1038/ngeo1593.

Berggren, M., del Giorgio, P.A., 2015. Distinct patterns of microbial metabolism associated to riverine dissolved organic carbon of different source and quality. J. Geophys. ResBiogeo. 120, 989-999. https://doi.org/10.1002/2015JG002963.

Bernhardt, J.R., Sunday, J.M., O'Connor, M.I., 2018. Metabolic theory and the temperaturesize rule explain the temperature dependence of population carrying capacity. Am. Nat. 192 (6), 687-697. https://doi.org/10.1086/700114.

Bonada, N., Resh, V.H., 2013. Mediterranean-climate streams and rivers: geographically separated but ecologically comparable freshwater systems. Hydrobiologia 719 (1), 1-29. https://doi.org/10.1007/s10750-013-1634-2.

Boulton, A.J. Boyero, L Covich, A.P. Dobson, M. Lake, P. S., Pearson, R. 2008 . Are tropical streams ecologically different from temperate streams? In: Dudgeon, D. (Ed.), Tropical Stream Ecology. Elsevier, London, UK, pp. 257-284 https://doi.org/10.1016/B978012088449-0.50011-X

Boyero, L., Ramirez, A., Dudgeon, D., Pearson, R.G., 2009. Are tropical streams really different? J. North. Am. Benthol. 28 (2), 397-403. https://doi.org/10.1899/08-146.1.

Boyero, L., Pearson, R.G., Dudgeon, D., Graça, M.A.S., Gessner, M.O., Albariño, R.J., ... Callisto M., 2011a. Global distribution of a key trophic guild contrasts with common latitudinal diversity patterns. Ecology 92 (9), 1839-1848. https://doi.org/10.1890/10-2244.1.

Boyero, L., Pearson, R.G., Gessner, M.O., Barmuta, L.A., Ferreira, V., Graça, M.A., ... Helson, J.E., 2011b. A global experiment suggests climate warming will not accelerate litter decomposition in streams but might reduce carbon sequestration. Ecol. Lett. 14 (3), 289-294. https://doi.org/10.1111/j.1461-0248.2010.01578.x.

Boyero, L., Cardinale, B.J., Bastian, M., Pearson, R.G., 2014. Biotic vs. abiotic control of decomposition: a comparison of the effects of simulated extinctions and changes in temperature. PLoS One 9 (1), e87426. https://doi.org/10.1371/journal.pone.0087426.

Brandt, L.A., King, J.Y., Milchunas, D.G., 2007. Effects of ultraviolet radiation on litter decomposition depend on precipitation and litter chemistry in a shortgrass steppe ecosystem. Glob. Chang. Biol. 13 (10), 2193-2205. https://doi.org/10.1111/j.13652486.2007.01428.x.

Brown, J.H., Gillooly, J.F., 2003. Ecological food webs: high-quality data facilitate theoretical unification. Proc. Natl. Acad. Sci. 100 (4), 1467-1468. https://doi.org/10.1073/ pnas.0630310100.

Brown, J.H., Gillooly, J.F., Allen, A.P., Savage, V.M., West, G.B., 2004. Toward a metabolic theory of ecology. Ecology 85 (7), 1771-1789. https://doi.org/10.1890/03-9000.

Burrows, R. M., Beesley, L., Douglas, M. M., Pusey, B .J., \& Kennard, M. J. 2020. Water velocity and groundwater upwelling influence benthic algal biomass in a sandy tropical river: implications for water-resource development. Hydrobiologia, 847(5), 1207-1219. doi: https://doi.org/10.1007/s10750-020-04176-3.

Bush, B.M., Ulyshen, M.D., Fair, C.G., Batzer, D.P., 2019. Assessing the effects of mesh enclosures on invertebrates and litter breakdown in a floodplain forest of the Southeastern USA. Wetl. Ecol. Manag. 27 (1), 149-156. https://doi.org/10.1007/s11273-018-9648-1.

Cherry, D.S., Guthrie, R.K., Harvey, R.S., 1974. Temperature influence on bacterial populations in three aquatic systems. Water Res. 8 (3), 149-155. https://doi.org/10.1016/ 0043-1354(74)90037-2.

Cionek, V.M., Alves, G.H.Z., Tófoli, R.M., Rodrigues-Filho, J.L., Dias, R.M., 2019. Brazil in the mud again: lessons not learned from Mariana dam collapse. Biodivers . Conserv. 28 (7), 1935-1938. https://doi.org/10.1007/s10531-019-01762-3. 
Cleven, E.J., Meyer, E.I., 2003. A sandy hyporheic zone limited vertically by a solid boundary. Arch. Hydrobiol. 157 (2), 267-288. https://doi.org/10.1127/0003-9136/2003/ 0157-0267.

Cole, J.J., Prairie, Y.T., Caraco, N.F., Mcdowell, W.H., Tranvik, L.J., Striegl, R.G., ... Melack, J., 2007. Plumbing the global carbon cycle: integrating inland waters into the terrestrial carbon budget. Ecosystems 10 (1), 171-184. https://doi.org/10.1007/s10021-0069013-8.

Colls, M., Timoner, X., Font, C., Sabater, S., Acuña, V., 2019. Effects of duration, frequency, and severity of the non-flow period on stream biofilm metabolism. Ecosystems 22 (6), 1393-1405. https://doi.org/10.1007/s10021-019-00345-1.

Cornut, J., Elger, A., Lambrigot, D., Marmonier, P., 2010. Early stages of leaf decomposition are mediated by aquatic fungi in the hyporheic zone of woodland streams. Freshw. Biol. 55 (12), 2541-2556. https://doi.org/10.1111/j.1365-2427.2010.02483.x.

Corti, R., Datry, T., Drummond, L., Larned, S.T., 2011. Natural variation in immersion and emersion affects breakdown and invertebrate colonization of leaf litter in a temporary river. Aquat. Sci. 73 (4), 537-550. https://doi.org/10.1007/s00027-011-0216-5.

Cunha, A., Almeida, A., Coelho, F.J.R.C., Gomes, N.C.M., Oliveira, V., Santos, A.L., 2010. Bacterial extracellular enzymatic activity in globally changing aquatic ecosystems. Curr. Res. Tech. Edu. Topics Applied Microbiol. Microbial Biotech. 1, 124-135.

Danielopol, D. L., Pospisil, P., Dreher, J., Mösslacher, F., Torreiter, P., Geiger-Kaiser, M., \& Gunatilaka, A. 2000. A groundwater ecosystem in the wetlands of the Danube at Vienna (Austria). In Wilkens, H., Culvers, D. C., \& Humphreys, W. F. (Eds), Caves and Other Subterranean Ecosystems. Ecosystems of the World (vol. 30, pp. 481-513). Amsterdam: Elsevier.

Datry, T., Larned, S.T., Tockner, K., 2014. Intermittent rivers: a challenge for freshwater ecology. BioScience 64 (3), 229-235. https://doi.org/10.1093/biosci/bit027.

Datry, T., Bonada, N., \& Boulton, A. J. 2017a. Conclusions: Recent advances and future prospects in the ecology and management of intermittent rivers and ephemeral streams. In T. Datry, N., Bonada, \& A. J. Boulton (Eds.), Intermittent rivers and ephemeral streams: Ecology and management (pp. 563-584). Amsterdam, The Netherlands: Academic Press. doi: 10.1016/B978-0-12-803835-2.00031-0.

Datry, T., Vander Vorste, R., Goïtia, E., Moya, N., Campero, M., Rodriguez, F., ... Oberdorff, T., $2017 \mathrm{~b}$. Context-dependent resistance of freshwater invertebrate communities to drying. Ecol. Evol. 7 (9), 3201-3211. https://doi.org/10.1002/ece3.2870.

Datry, T., Boulton, A.J., Bonada, N., Fritz, K., Leigh, C., Sauquet, ... Dahm, C.N., 2018a. Flow intermittence and ecosystem services in rivers of the Anthropocene. J. Appl. Ecol. 55 (1), 353-364. https://doi.org/10.1111/1365-2664.12941.

Datry, T., Foulquier, A., Corti, R., von Schiller, D., Tockner, K., Mendoza-Lera, ... Zoppini, A., 2018b. A global analysis of terrestrial plant litter dynamics in non-perennial waterways. Nat. Geosci. 11, 497-503. doi: https://doi.org/10.1038/s41561-018-0134-4.

Deng, L., Krauss, S., Feichtmayer, J., Hofmann, R., Arndt, H., Griebler, C., 2014. Grazing of heterotrophic flagellates on viruses is driven by feeding behavior. Environ. Microbiol. Rep. 6 (4), 325-330. https://doi.org/10.1111/1758-2229.12119.

Di Castri, F., Hansen, A., Holland, M.M., 1988. A new look at eco-tones: emerging international projects on landscape boundaries. Biol. Int. (Speccial Issuse) 17, 1-163.

Domisch, S., Araújo, M.B., Bonada, N., Pauls, S.U., Jähnig, S.C., Haase, P., 2013. Modelling distribution in European stream macroinvertebrates under future climates. Glob. Chang. Biol. 19 (3), 752-762. https://doi.org/10.1111/gcb.12107.

Dossena, M., Yvon-Durocher, G., Grey, J., Montoya, J.M., Perkins, D.M., Trimmer, M., Woodward, G., 2012. Warming alters community size structure and ecosystem functioning. Proc. Biol. Sci. 279 (1740), 3011-3019. https://doi.org/10.1098/rspb.2012.0394.

Drake, T.W., Raymond, P.A., Spencer, R.G., 2018. Terrestrial carbon inputs to inland waters: a current synthesis of estimates and uncertainty. Limnol. Oceanogr. Lett. 3 (3), 132-142. https://doi.org/10.1002/lol2.10055.

Edwards, A.M., Robinson, J.P., Plank, M.J., Baum, J.K., Blanchard, J.L., 2017. Testing and recommending methods for fitting size spectra to data. Methods Ecol. Evol. 8, 57-67. https://doi.org/10.1111/2041-210X.12641.

Escobar, H., 2015. Mud tsunami wreaks ecological havoc in Brazil. Science 350 (6265), 1138-1139. https://doi.org/10.1126/science.350.6265.1138.

Evans, L.E., Hirst, A.G., Kratina, P., Beaugrand, G., 2020. Temperature-mediated changes in zooplankton body size: large scale temporal and spatial analysis. Ecography 43 (4), 581-590. https://doi.org/10.1111/ecog.04631.

Findlay, S., Quinn, J.M., Hickey, C.W., Burrell, G., Downes, M., 2001. Effects of land use and riparian flowpath on delivery of dissolved organic carbon to streams. Limnol. Oceanogr. 46 (2), 345-355. https://doi.org/10.4319/lo.2001.46.2.0345.

Foght, J., 2008. Anaerobic biodegradation of aromatic hydrocarbons: pathways and prospects. J. Mol. Microbiol. Biotechnol. 15 (2-3), 93-120. https://doi.org/10.1159/ 000121324.

Follstad Shah, J.J., Kominoski, J.S., Ardón, M., Dodds, W.K., Gessner, M.O., Griffiths, N.A., , Manning, D.W., 2017. Global synthesis of the temperature sensitivity of leaf litter breakdown in streams and rivers. Global Change Biol. 23 (8), 3064-3075. https:// doi.org/10.1111/gcb.13609.

Friedlingstein, P., Jones, M., O'sullivan, M., Andrew, R., Hauck, J., Peters, G., ... Zaehle, S., 2019. Global carbon budget 2019. Earth System Science Data 11 (4), 1783-1838. https://doi.org/10.5194/essd-11-1783-2019.

Gasith, A., Resh, V.H., 1999. Streams in Mediterranean climate regions: abiotic influences and biotic responses to predictable seasonal events. Annu. Rev. Ecol. Evol. Syst. 30 (1), 51-81. https://doi.org/10.1146/annurev.ecolsys.30.1.51.

Gessner, M.O., Chauvet, E., Dobson, M., 1999. A perspective on leaf litter breakdown in streams. Oikos 85 (2), 377-384. https://doi.org/10.2307/3546505.

Gibert, J., Culver, D.C., Dole-Olivier, M.J., Malard, F., Christman, M.C., Deharveng, L., 2009. Assessing and conserving groundwater biodiversity: synthesis and perspectives. Freshw. Biol. 54 (4), 930-941. https://doi.org/10.1111/j.1365-2427.2009.02201.x.

Gonçalves, J.F., Graça, M.A.S., Callisto, M., 2007. Litter decomposition in a Cerrado savannah stream is retarded by leaf toughness, low dissolved nutrients and a low density of shredders. Freshw. Biol. 52 (8), 1440-1451. https://doi.org/10.1111/j.13652427.2007.01769.x

González-Bergonzoni, I., Meerhoff, M., Davidson, T.A., Teixeira-de Mello, F., Baattrup-Pedersen, A., Jeppesen, E., 2012. Meta-analysis shows a consistent and strong latitudinal pattern in fish omnivory across ecosystems. Ecosystems 15 (3), 492-503. https://doi. org/10.1007/s10021-012-9524-4.

Graça, M.A.S., 2001. The role of invertebrates on leaf litter decomposition in streams: a review. Nt. Rev. Hydrobiol. 86 (4-5), 383-394. https://doi.org/10.1002/1522-2632 (200107)86:4/5<383::AID-IROH383>3.0.CO;2-D.

Graça, M.A.S., Hyde, K., Chauvet, E., 2016. Aquatic hyphomycetes and litter decomposition in tropical: subtropical low order streams. Fungal Ecol. 19, 182-189. https://doi.org/ 10.1016/j.funeco.2015.08.001

Griebler, C., Avramov, M., 2015. Groundwater ecosystem services: a review. Freshw. Sci. 34 (1), 355-367. https://doi.org/10.1086/679903.

Heino, J., Melo, A.S., Jyrkänkallio-Mikkola, J., Petsch, D.K., Saito, V.S., Tolonen, K.T., .. Soininen, J., 2018. Subtropical streams harbour higher genus richness and lower abundance of insects compared to boreal streams, but scale matters. J. Biogeogr. 45 (9), 1983-1993. https://doi.org/10.1111/jbi.13400.

Hill, B.H., Kolka, R.K., McCormick, F.H., Starry, M.A., 2014. A synoptic survey of ecosystem services from headwater catchments in the United States. Ecosyst. Serv. 7, 106-115. https://doi.org/10.1016/j.ecoser.2013.12.004.

Hose, G., Stumpp, C., 2019. Architects of the underworld: bioturbation by groundwater invertebrates influences aquatic hydraulic properties. Aquat. Sci. 81 (20), 20. https:// doi.org/10.1007/s00027-018-0613-0.

Hotchkiss, E.R., Hall Jr., R.O., Sponseller, R.A., Butman, D., Klaminder, J., Laudon, H., Rosvall, M., Karlsson, J., 2015. Sources of and processes controlling $\mathrm{CO}_{2}$ emissions change with the size of streams and rivers. Nat. Geosci. 8, 696. https://doi.org/10.1038/ngeo2507.

House, W.A., 2003. Geochemical cycling of phosphorus in rivers. Appl. Geochem. 18 (5), 739-748. https://doi.org/10.1016/S0883-2927(02)00158-0.

Howarth, R. G., Billen, G., Swaney, D., Townsend, A., Jaworski, N., Lajtha, K., ... Zhao-Liang, Z. 1996. In Howarth R.W. (eds), Nitrogen Cycling in the North Atlantic Ocean and its Watersheds (pp. 75-139). Dordrecht: Springer. doi: 10.1007/978-94-009-1776-73.

Jackson, R.B., Carpenter, S.R., Dahm, C.N., McKnight, D.M., Naiman, R.J., Postel, S.L., Running, S.W., 2001. Water in a changing world. Ecol. Appl. 11, 1027-1045. https:// doi.org/10.1890/1051-0761(2001)011[1027:WIACW]2.0.CO;2.

Jaeger, A., Coll, C., Posselt, M., Mechelke, J., Rutere, C., Betterle, A., ... Singh, T., 2019. Using recirculating flumes and a response surface model to investigate the role of hyporheic exchange and bacterial diversity on micropollutant half-lives. Environ. Sci-Proc. Imp. 21 (12), 2093-2108. https://doi.org/10.1039/C9EM00327D.

James, F.C., 1970. Geographic size variation in birds and its relationship to climate. Ecology 51 (3), 365-390. https://doi.org/10.2307/1935374.

Johnson, S.L., Jones, J.A., 2000. Stream temperature responses to forest harvest and debris flows in western Cascades. Oregon. Can. J. Fish. Aquat. Sci. 57 (S2), 30-39.

Junk, W.J., Bayley, P.B., Sparks, R.E., 1989. The flood pulse concept in river-floodplain systems. Can. J. Fish. Aquat. Sci. 106, 110-127. https://doi.org/10.1007/978-94-0158212-4_14.

Jurado, A., Vàzquez-Suñé, E., Carrera, J., de Alda, M.L., Pujades, E., Barceló, D., 2012. Emerging organic contaminants in groundwater in Spain: a review of sources, recent occurrence and fate in a European context. Sci. Total Environ. 440, 82-94. https://doi.org/ 10.1016/j.scitotenv.2012.08.029.

Kelly, D.W., Dick, J.T., Montgomery, W.I., 2002. The functional role of Gammarus (Crustacea, Amphipoda): shredders, predators, or both? Hydrobiologia 485 (1-3), 199-203. https://doi.org/10.1023/A:1021370405349.

Kelly, D.J., Bothwell, M.L., Schindler, D.W., 2003. Effects of solar ultraviolet radiation on stream benthic communities: an intersite comparison. Ecology 84 (10), 2724-2740. https://doi.org/10.1890/02-0658.

Kerr, S.R., Dickie, L.M., 2001. The Biomass Spectrum: A Predator-prey Theory of Aquatic Production. Columbia University Press, New York, USA https://doi.org/10.2307/ 3071789.

Kolvenbach, B.A., Helbling, D.E., Kohler, H.-P.E., Corvini, P.F.X., 2014. Emerging chemicals and the evolution of biodegradation capacities and pathways in bacteria. Curr Opin. Biotechnol. 27, 8-14. https://doi.org/10.1016/j.copbio.2013.08.017.

Krause, S., Hannah, D.M., Fleckenstein, J.H., 2009. Hyporheic hydrology: interactions at the groundwater-surface water interface. Hydrol. Process. 23 (15), 2103-2263. https:// doi.org/10.1002/hyp.7366.

Krause, S., Hannah, D.M., Fleckenstein, J.H., Heppell, C.M., Kaeser, D., Pickup, R., Pinay, G. Wood, P.J., 2011a. Inter-disciplinary perspectives on processes in the hyporheic zone. Ecohydrology 4 (4), 481-499. https://doi.org/10.1002/eco.176.

Krause, S., Hannah, D.M., Sadler, J.P., Wood, P.J., 2011b. Ecohydrology on the edge: interactions across the interfaces of wetland, riparian and groundwater-based ecosystems. Ecohydrology 4 (4), 477-480. https://doi.org/10.1002/eco.240.

Krause, S., Lewandowski, J., Grimm, N.B., Hannah, D.M., Pinay, G., ... Turk, V., 2017. Ecohydrological interfaces as hot spots of ecosystem processes. Water Resour. Res. 53 (8), 6359-6376. https://doi.org/10.1002/2016WR019516.

Larned, S.T., Datry, T., Arscott, D.B., Tockner, K., 2010. Emerging concepts in temporaryriver ecology. Freshw. Biol. 55 (4), 717-738. https://doi.org/10.1111/j.13652427.2009.02322.x

Leaper, R., Huxham, M., 2002. Size constraints in a real food web: predator, parasite and prey body-size relationships. Oikos 99 (3), 443-456. https://doi.org/10.1034/j.16000706.2002.10888.x

Leite-Rossi, L.A., Saito, V.S., Cunha-Santino, M.B., Trivinho-Strixino, S., 2016. How does leaf litter chemistry influence its decomposition and colonization by shredder Chironomidae (Diptera) larvae in a tropical stream? Hydrobiologia 771 (1), 119-130. https://doi.org/10.1007/s10750-015-2626-1.

Lennon, J.T., Cottingham, K.L., 2008. Microbial productivity in variable resource environments. Ecology 89 (4), 1001-1014. https://doi.org/10.1890/07-1380.1. 
Lepers, E., Lambin, E.F., Janetos, A.C., DeFries, R., Achard, F., Ramankutty, N., Scholes, R.J., 2005. A synthesis of information on rapid land-cover change for the period 1981-2000. BioScience 55 (2), 115-124. https://doi.org/10.1641/0006-3568(2005) 055[0115:ASOIOR]2.0.CO;2.

Lewandowski, J., Putschew, A., Schwesig, D., Neumann, C., Radke, M., 2011. Fate of organic micropollutants in the hyporheic zone of a eutrophic lowland stream: results of a preliminary field study. Sci. Total Environ. 409 (10), 1824-1835. https://doi.org/ 10.1016/j.scitotenv.2011.01.028

Liao, K., Bai, Y., Huo, Y., Jian, Z., Hu, W., Zhao, C., Qu, J., 2018. Integrating microbial biomass, composition and function to discern the level of anthropogenic activity in a river ecosystem. Environ. Int. 116, 147-155. https://doi.org/10.1016/j.envint.2018.04.003.

Majdi, N., Traunspurger, W., 2017. Leaf fall affects the isotopic niches of meiofauna and macrofauna in a stream food web. Food Webs 10, 5-14. https://doi.org/10.1016/j. fooweb.2017.01.002.

Majdi, N., Boiché, A., Traunspurger, W., Lecerf, A., 2014. Predator effects on a detritusbased food web are primarily mediated by non-trophic interactions. J. Anim. Ecol. 83 (4), 953-962. https://doi.org/10.1111/1365-2656.12189.

Majdi, N., Colls, M., Weiss, L., Acuña, V., Sabater, S., Traunspurger, W., 2020. Duration and frequency of non-flow periods affect the abundance and diversity of stream meiofauna. Freshw. Biol. 65 (11), 1906-1922. https://doi.org/10.1111/fwb.13587.

Maurice, L., Bloomfield, J., 2012. Stygobitic invertebrates in groundwater-a review from a hydrogeological perspective. Fr. Rev. 5 (1), 51-71. https://doi.org/10.1608/FRJ5.1.443.

McArthur, J.V., Barnes, J.R., Hansen, B.J., Leff, L.G., 1988. Seasonal dynamics of leaf litter breakdown in a Utah alpine stream. J. North. Am. Benthol. 7 (1), 44-50. https://doi. org $/ 10.2307 / 1467830$

McClain, M.E., Elsenbeer, H., 2001. Terrestrial inputs to Amazon streams and internal biogeochemical processing. In: McClain, M.E., Victoria, R.L., Richey, J.E. (Eds.), The Biogeochemistry of the Amazon Basin. Oxford University Press, New York, pp. 185-208.

Mechelke, J., Longrée, P., Singer, H., Hollender, J., 2019. Vacuum-assisted evaporative concentration combined with LC-HRMS/MS for ultra-trace-level screening of organic micropollutants in environmental water samples. Anal. Bioanal. Chem. 411 (12), 2555-2567. https://doi.org/10.1007/s00216-019-01696-3.

Meckenstock, R.U., Elsner, M., Griebler, C., Lueders, T., Stumpp, C., Dejonghe, W., ... van Breukelen, B., 2015. Biodegradation: Updating the concepts of control for microbial clean-up in contaminated aquifers. Environ. Sci. Technol. 49 (12), 7073-7081. https://doi.org/10.1021/acs.est.5b00715.

Mendes, F., Kiffer Jr., W.P., Moretti, M.S., 2017. Structural and functional composition of invertebrate communities associated with leaf patches in forest streams: a comparison between mesohabitats and catchments. Hydrobiologia 800, 115-127. https://doi. org/10.1007/s10750-017-3249-5.

Moosdorf, N., Stieglitz, T., Waska, H., Dürr, H.H., Hartmann, J., 2015. Submarine groundwater discharge from tropical islands: a review. Grundwasser 20 (1), 53-67. https://doi. org/10.1007/s00767-014-0275-3.

Morellato, L.P.C., Talora, D.C., Takahasi, A., Bencke, C.C., Romera, E.C., Zipparro, V.B., 2000. Phenology of Atlantic rain forest trees: a comparative study ${ }^{1}$. Biotropica 32 (4b), 811-823. https://doi.org/10.1111/j.1744-7429.2000.tb00620.x.

Nessimian, J.L., Dorvillé, L.F.M., Sanseverino, A.M., Baptista, D.F., 1998. Relation between flood pulse and functional composition of the macroinvertebrate benthic fauna in the lower Rio Negro, Amazonas, Brazil. Amazoniana 15 (1/2), 35-50.

Nilsson, C., Lepori, F., Malmqvist, B., Törnlund, E., Hjerdt, N., Helfield, J.M., ... Lundqvist, H., 2005. Forecasting environmental responses to restoration of rivers used as log floatways: an interdisciplinary challenge. Ecosystems 8 (7), 779-800. https://doi. org/10.1007/s10021-005-0030-9.

O'Connell, M., Baldwin, D.S., Robertson, A.I., Rees, G., 2000. Release and bioavailability of dissolved organic matter from floodplain litter: influence of origin and oxygen levels. Freshw. Biol. 45 (3), 333-342. https://doi.org/10.1111/j.1365-2427.2000.00627.x.

O'Gorman, E.J., Zhao, L., Pichler, D.E., Adams, G., Friberg, N., Rall, B.C., Seeney, A., Zhang, H., Reuman, D.C., Woodward, G., 2017. Unexpected changes in community size structure in a natural warming experiment. Nat. Clim. Chang. 7 (9), 659-663. https://doi.org/ 10.1038/nclimate3368.

Olsson, T., Söderström, O., 1978. Springtime migration and growth of Parameletus chelifer (Ephemeroptera) in a temporary stream in northern Sweden. Oikos 31, 284-289. https://doi.org/10.2307/3543652.

Padial, A.A., Thomaz, S.M., 2006. Effects of flooding regime upon the decomposition of Eichhornia azurea (Sw.) Kunth measured on a tropical, flow-regulated floodplain (Paraná River, Brazil). River Res. Appl. 22 (7), 791-801. https://doi.org/10.1002/ rra.936.

Pascoal, C., Cássio, F., Marcotegui, A., Sanz, B., Gomes, P., 2005. Role of fungi, bacteria, and invertebrates in leaf litter breakdown in a polluted river. J. North. Am. Benthol. 24 (4), 784-797. https://doi.org/10.1899/05-010.1.

Peralta-Maraver, I., Reiss, J., Robertson, A.L., 2018. Interplay of hydrology, community ecology and pollutant attenuation in the hyporheic zone. Sci. Total Environ. 610, 267-275. https://doi.org/10.1016/j.scitotenv.2017.08.036.

Peralta-Maraver, I., Perkins, D.M., Thompson, M.S., Fussmann, K., Reiss, J., Robertson, A.L., 2019a. Comparing biotic drivers of litter breakdown across stream compartments. J. Anim. Ecol. 88 (8), 1146-1157. https://doi.org/10.1111/1365-2656.13000.

Peralta-Maraver, I., Robertson, A.L., Perkins, D.M., 2019b. Depth and vertical hydrodynamics constrain the size structure of a lowland streambed community. Biol. Lett. 15 (7), 20190317. https://doi.org/10.1098/rsbl.2019.0317.

Perkins, D.M., Durance, I., Edwards, F.K., Grey, J., Hildrew, A.G., Jackson, M., ... Woodward, G., 2018. Bending the rules: exploitation of allochthonous resources by a toppredator modifies size-abundance scaling in stream food webs. Ecol. Lett. 21 (12), 1771-1780. https://doi.org/10.1111/ele.13147.

Petchey, O.L., Belgrano, A., 2010. Body-size distributions and size-spectra: universal indicators of ecological status? Biol. Lett. 6, 434-437. https://doi.org/10.1098/rsbl.2010.0240.
Peterson, B.J., Wollheim, W.M., Mulholland, P.J., Webster, J.R., Meyer, J.L., Tank, J.L., .. McDowell, W.H., 2001. Control of nitrogen export from watersheds by headwater streams. Science 292 (5514), 86-90. https://doi.org/10.1126/science.1056874.

Posselt, M., Mechelke, J., Rutere, C., Coll, C., Jaeger, A., Raza, M., ... Horn, M.A., 2020. Bacterial diversity controls transformation of wastewater-derived organic contaminants in River-Simulating Flumes. Environ. Sci. Technol. 54 (9), 5467-5479. https://doi.org/ 10.1021/acs.est.0c00767.

Prather, C.M., Pelini, S.L., Laws, A., Rivest, E., Woltz, M., Bloch, C.P., ... Joern, A., 2013. Invertebrates, ecosystem services and climate change. Biol. Rev. 88 (2), 327-348. https:// doi.org/10.1111/brv.12002.

Pringle, C.M., Paaby-Hansen, P., Vaux, P.D., Goldman, C.R., 1986. In situ nutrient assays of periphyton growth in a lowland Costa Rican stream. Hydrobiologia 134, 207-213. https://doi.org/10.1007/BF00008489.

Rahm, B.G., Hill, N.B., Shaw, S.B., Riha, S.J., 2016. Nitrate dynamics in two streams impacted by wastewater treatment plant discharge: point sources or sinks? J. Am. Water Resour. As. 52 (3), 592-604. https://doi.org/10.1111/1752-1688.12410.

Raymond, P.A., Hartmann, J., Lauerwald, R., Sobek, S., McDonald, C., Hoover, M., Kortelainen, P., 2013. Global carbon dioxide emissions from inland waters. Nature 503 (7476), 355-359. https://doi.org/10.1038/nature12760.

Reche, I., Pace, M.L., Cole, J.J., 1998. Interactions of photobleaching and inorganic nutrients in determining bacterial growth on colored dissolved organic carbon. Microb. Ecol. 36 (3-4), 270-280. https://doi.org/10.1007/s002489900114.

Refsgaard, J.C., Auken, E., Bamberg, C.A., Christensen, B.S., Clausen, T., Dalgaard, E., ... He, X 2014. Nitrate reduction in geologically heterogeneous catchments-A framework for assessing the scale of predictive capability of hydrological models. Sci. Total Environ. 468, 1278-1288. https://doi.org/10.1016/j.scitotenv.2013.07.042.

Regnier, P., Friedlingstein, P., Ciais, P., Mackenzie, F.T., Gruber, N., Janssens, I.A., ... Arndt, S. 2013. Anthropogenic perturbation of the carbon fluxes from land to ocean. Nature geosci. 6 (8), 597-607. https://doi.org/10.1038/ngeo1830.

Reiss, J., Perkins, D.M., Fussmann, K.E., Krause, S., Canhoto, C., Romeijn, P., Robertson, A.L., 2019. Groundwater flooding: ecosystem structure following an extreme recharge event. Sci. Total Environ. 652, 1252-1260. https://doi.org/10.1016/j. scitotenv.2018.10.216.

Robertson, A.L., Smith, J.W.N., Johns, T., Proudlove, G.S., 2009. The distribution and diversity of stygobites in Great Britain: an analysis to inform groundwater management. Q. J. Eng. Geol. 42 (3), 359-368. https://doi.org/10.1144/1470-9236/08-046.

Schaper, J.L., Seher, W., Nützmann, G., Putschew, A., Jekel, M., Lewandowski, J., 2018. The fate of polar trace organic compounds in the hyporheic zone. Water Resour. 140, 158-166. https://doi.org/10.1016/j.watres.2018.04.040.

Schaper, J.L., Posselt, M., Bouchez, C., Jaeger, A., Nuetzmann, G., Putschew, A., Lewandowski, J., 2019. Fate of Trace Organic Compounds in the Hyporheic Zone: Influence of Retardation, the Benthic Biolayer, and Organic Carbon. Environ. Sci. Technol. 53 (8), 4224-4234. https://doi.org/10.1021/acs.est.8b06231.

Schemske, D.W., Mittelbach, G.G., Cornell, H.V., Sobel, J.M., Roy, K., 2009. Is there a latitudinal gradient in the importance of biotic interactions? Annu. Rev. Ecol. Evol. Syst. 40 245-269. https://doi.org/10.1146/annurev.ecolsys.39.110707.173430.

Schmid, P.E., Tokeshi, M., Schmid-Araya, J.M., 2000. Relation between population density and body size in stream communities. Science 289 (5484), 1557-1560. https://doi org/10.1126/science.289.5484.1557.

Schneider, I., Topalova, Y., 2009. Structural and functional changes in river microbial communities after dairy wastewater discharge. Biotechnol. Biotechnol. Equip. 23 (2), 1210-1216. https://doi.org/10.1080/13102818.2009.10818576.

Seitzinger, S., Harrison, J.A., Böhlke, J.K., Bouwman, A.F., Lowrance, R., Peterson, B., ... Drecht, G.V., 2006. Denitrification across landscapes and waterscapes: a synthesis. Ecol. Appl. 16 (6), 2064-2090. https://doi.org/10.1890/1051-0761(2006)016[2064: DALAWA]2.0.CO;2

Shumilova, O., Zak, D., Datry, T., von Schiller, D., Corti, R., Foulquier, A., ... Arce, M.I., 2019. Simulating rewetting events in intermittent rivers and ephemeral streams: A global analysis of leached nutrients and organic matter. Global Change Biol. 25 (5), 1591-1611. https://doi.org/10.1111/gcb.14537.

Sibly, R.M., Brown, J.H., Kodric-Brown, A., 2012. Metabolic Ecology: A Scaling Approach. John Wiley \& Sons, New Jewrsey, USA.

Silva-Araújo, M., Silva-Junior, E. F., Neres-Lima, V., Feijó-Lima, R., Tromboni, F., LourençoAmorim, C., ... \& Zandonà, E. 2020. Effects of riparian deforestation on benthic invertebrate community and leaf processing in Atlantic forest streams. Perspect. Ecol. Conserv. (in press. doi: https://doi.org/10.1016/j.pecon.2020.09.004.

Sket, B., 1999. High biodiversity in hypogean waters and its endangerment-the situation in Slovenia, the Dinaric karst, and Europe. Crustaceana 72 (8), 767-779. https://doi org/10.1163/156854099503951.

Sponseller, R.A., Benfield, E.F., 2001. Influences of land use on leaf breakdown in southern Appalachian headwater streams: a multi-scale analysis. J. North. Am. Benthol. 20 (1) 44-59. https://doi.org/10.2307/1468187.

Steward, A.L., Marshall, J.C., Sheldon, F., Harch, B., Choy, S., Bunn, S.E., Tockner, K., 2011. Terrestrial invertebrates of dry river beds are not simply subsets of riparian assemblages. Aquat. Sci. 73, 551-566. https://doi.org/10.1007/s00027-011-0217-4.

Stubbington, R., Datry, T., 2013. The macroinvertebrate seedbank promotes community persistence in temporary rivers across climate zones. Freshw. Biol. 58 (6), 1202-1220. https://doi.org/10.1111/fwb.12121.

Stubbington, R., England, J., Wood, P. J., \& Sefton, C. E. 2017. Temporary streams in temperate zones: recognizing, monitoring and restoring transitional aquatic-terrestrial ecosystems. Wiley Interdiscip. Rev. Water. 4(4), e1223. doi: 10.1002/wat2.1223.

Sweeney, B.W., Bott, T.L., Jackson, J.K., Kaplan, L.A., Newbold, J.D., Standley, L.J., ... Horwitz, R.J., 2004. Riparian deforestation, stream narrowing, and loss of stream ecosystem services. Proc. Natl. Acad. Sci. U.S.A. 101 (39), 14132-14137. https://doi.org/10.1073/ pnas.0405895101. 
Taniwaki, R.H., Piggott, J.J., Ferraz, S.F., Matthaei, C.D., 2017. Climate change and multiple stressors in small tropical streams. Hydrobiologia 793 (1), 41-53. https://doi.org/ 10.1007/s10750-016-2907-3.

Taniwaki, R.H., Matthaei, C.D., Cardoso, T.K., Ferraz, S.F., Martinelli, L.A., Piggott, J.J., 2019. The effect of agriculture on the seasonal dynamics and functional diversity of benthic biofilm in tropical headwater streams. Biotropica 51 (1), 18-27. https://doi.org/ 10.1111/btp.12617.

Tank, J.L., Webster, J.R., 1998. Interaction of substrate and nutrient availability on wood biofilm processes in streams. Ecology 79 (6), 2168-2179. https://doi.org/10.1890/ 0012-9658(1998)079[2168:IOSANA]2.0.CO;2.

Tank, J.L., Rosi-Marshall, E.J., Griffiths, N.A., Entrekin, S.A., Stephen, M.L., 2010. A review of allochthonous organic matter dynamics and metabolism in streams. J. North. Am. Benthol. 29 (1), 118-146. https://doi.org/10.1899/08-170.1.

Thompson, P.L., Bärlocher, F., 1989. Effect of pH on leaf breakdown in streams and in the laboratory. J. North. Am. Benthol. 8 (3), 203-210. https://doi.org/10.2307/1467323.

Tiegs, S. D., Costello, D. M., Isken, M. W., Woodward, G., McIntyre, P. B., Gessner, M. O., ... \& Albariño, R. 2019. Global patterns and drivers of ecosystem functioning in rivers and riparian zones. Sci. Adv. 5(1), eaav0486. doi: 10.1126/sciadv.aav0486.

Tockner, K., Stanford, J.A., 2002. Riverine flood plains: present state and future trends. Environ. Conserv. 29 (3), 308-330. https://doi.org/10.1017/S037689290200022X.

Tooth, S., Nanson, G.C., 2000. The role of vegetation in the formation of anabranching channels in an ephemeral river, Northern plains, arid central Australia. Hydrol. Process. 14 (16-17), 3099-3117. https://doi.org/10.1002/1099-1085(200011/12)14: 16/17<3099::AID-HYP136>3.0.CO;2-4.

Vannote, R.L., Minshall, G.W., Cummins, K.W., Sedell, J.R., Cushing, C.E., 1980. The river continuum concept. Can. J. Fish. Aquat. Sci. 37 (1), 130-137. https://doi.org/10.1139/f80017.

Vitousek, P.M., Aber, J.D., Howarth, R.W., Likens, G.E., Matson, P.A., Schindler, D.W., ... Tilman, D.G., 1997. Human alteration of the global nitrogen cycle: sources and consequences. Ecol. Appl. 7 (3), 737-750. https://doi.org/10.1890/1051-0761(1997)007 [0737:HAOTGN]2.0.CO;2.

Von Schiller, D., Datry, T., Corti, R., Foulquier, A., Tockner, K., Marcé, R., ... Mendoza-Lera, C., 2019. Sediment respiration pulses in intermittent rivers and ephemeral streams. Global Biogeochem. Cycles. 33 (10), 1251-1263. https://doi.org/10.1029/2019GB006276.

Walalite, T., Dekker, S.C., Keizer, F.M., Kardel, I., Schot, P.P., deJong, S.M., Wassen, M.J., 2016. Flood water hydrochemistry patterns suggest floodplain sink function for dissolved solids from the Songkhram Monsoon River (Thailand). Wetlands 36, 995-1008. https://doi.org/10.1007/s13157-016-0814-z.

Wang, S.Y., Sudduth, E.B., Wallenstein, M.D., Wright, J.P., Bernhardt, E.S., 2011. Watershed urbanization alters the composition and function of stream bacterial communities. PLoS One 6 (8), e22972. https://doi.org/10.1371/journal.pone.0022972.
Wang, F., Lin, D., Li, W., Dou, P., Han, L., Huang, M., ... Yao, J., 2020. Meiofauna promotes litter decomposition in stream ecosystems depending on leaf species. Ecol. Evol. 10 (17), 9257-9270. https://doi.org/10.1002/ece3.6610.

Wantzen, K.M., Wagner, R., 2006. Detritus processing by invertebrate shredders: a neotropical-temperate comparison. J. North. Am. Benthol. 25 (1), 216-232. https:// doi.org/10.1899/0887-3593(2006)25[216:DPBISA]2.0.CO;2.

Wantzen, K.M., Yule, C.M., Mathooko, J.M., Pringle, C.M., Dudgeon, D., 2008. Organic matter processing in tropical streams. In: Dudgeon, D. (Ed.), Tropical Stream Ecology.

Webster, J.R., Benfield, E.F., 1986. Vascular plant breakdown in freshwater ecosystems. Annu. Rev. Ecol. Evol. Syst. 17, 567-594. https://doi.org/10.1146/annurev. es.17.110186.003031 (Elsevier, London, pp. 43-64).

Weitere, M., Scherwass, A., Sieben, K.T., Arndt, H., 2005. Planktonic food web structure and potential carbon flow in the lower river Rhine with a focus on the role of protozoans. River Res. Appl. 21 (5), 535-549. https://doi.org/10.1002/rra.825.

Weitowitz, D., Robertson, A., Bloomfield, J., Maurice, L., Reiss, J., 2019. Obligate groundwater crustaceans mediate biofilm interactions in a subsurface food web. Freshwater Science 38 (3), 491-502. https://doi.org/10.1086/704751.

Wetzel, R.G., 2001. Limnology: Lake and River Ecosystems. Academic Press, San Diego.

White, E.P., Ernest, S.M., Kerkhoff, A.J., Enquist, B.J., 2007. Relationships between body size and abundance in ecology. Trends Ecol. Evol. 22 (6), 323-330. https://doi.org/ 10.1016/j.tree.2007.03.007.

Williams, C.J., Yamashita, Y., Wilson, H.F., Jaffé, R., Xenopoulos, M.A., 2010. Unraveling the role of land use and microbial activity in shaping dissolved organic matter characteristics in stream ecosystems. Limnol. Oceanogr. 55 (3), 1159-1171. https://doi.org/ 10.4319/lo.2010.55.3.1159.

Withers, P.J.A., Jarvie, H.P., 2008. Delivery and cycling of phosphorus in rivers: a review. Sci. Total Environ. 400 (1-3), 379-395. https://doi.org/10.1016/j.scitotenv.2008.08.002.

Wold, A.P., Hershey, A.E., 1999. Spatial and temporal variability of nutrient limitation in 6 North Shore tributaries to Lake Superior. J. North. Am. Benthol. 18 (1), 2-14. https:// doi.org/10.2307/1468005.

Woodward, G., Gessner, M.O., Giller, P.S., Gulis, V., Hladyz, S., Lecerf, A., ... Dobson, M., 2012. Continental-scale effects of nutrient pollution on stream ecosystem functioning. Science 336 (6087), 1438-1440. https://doi.org/10.1126/science.1219534.

Wright, J.S., 2002. Plant diversity in tropical forests: a review of mechanisms of species coexistence. Oecologia 130 (1), 1-14. https://doi.org/10.1007/s004420100809.

Zhang, H., Yuan, W., Dong, W., Liu, S., 2014. Seasonal patterns of litterfall in forest ecosystem worldwide. Ecol. Complex. 20, 240-247. https://doi.org/10.1016/j.ecocom.2014.01.003.

Zuur, A.F., Ieno, E.N., Walker, N.J., Saveliev, A.A., Smith, G.M., 2009. Mixed Effects Models and Extensions in Ecology with R. Springer, New York. 